\title{
RECEPTOR ELEMENTS IN THE COXAL REGION OF DECAPODA CRUSTACEA
}

\author{
By J. S. Alexandrowicz ${ }^{1}$ \\ Plymouth Laboratory \\ and MARY WHITEAR \\ Department of Zoology, University College London
}

(Plates I and II; Text-figs. I-8)

Investigation of the proprioceptive organs in the coxal region of crustaceans, the results of which are here recorded, have been to a large extent stimulated by the evidence put forward by physiologists. The probability of the occurrence of such organs across the thoracico-coxal articulations was pointed out by Prof. S. Dijkgraaf in 1955, in a letter to one of the authors (J.S.A.). During systematic study of sensory organs in the legs of crustaceans, made in the autumn of 1956 by the present writers, it was found that in the region of all articulations there are one or two sensory organs consisting of a connective tissue strand and a row of bipolar nerve cells. A paper by Dijkgraaf (1956a) on the compensatory eye movements in Palinurus vulgaris, in which it is concluded that some proprioceptors in the coxal region must be present, gave us the incentive to persist in examination of this region in spite of considerable technical difficulties. The results obtained fully confirmed Dijkgraaf's view and the presence of receptor organs in several species has now been established. It has been found, moreover, that in the coxal region they are of several kinds differing in their structure and arrangement from any receptor known as yet. The description of them is given below.

The investigations were made chiefly with the lobster, Homarus vulgaris, and the crabs Maia squinado and Carcinus maenas. Some observations were made on Palinurus vulgaris, Astacus astacus, Eupagurus bernhardus and Cancer pagurus. Methylene blue was used for staining. Usually the tissues were immersed in a weak solution made by adding ro-15 drops of $0.5 \%$ methylene blue in distilled water to $100 \mathrm{ml}$. of sea water. The nerves of the receptor organs stain in every such preparation provided they are well exposed, but this is a condition not easily fulfilled, as the organs are in a position not at all convenient for observation. Another procedure consisted in injecting a stronger solution of the dye (one part of the $0.5 \%$ solution mixed

1 The continuation of this work at the Plymouth Laboratory has been made possible by a grant from the Royal Society, for which the writer wishes to express his sincere gratitude. 
with three to six parts of sea water) directly into the region to be examined, before the animal was dissected. The results were not so consistent as with the immersion method, but sometimes gave better staining of the more deeply situated elements. Some hints on the dissection of the animals are given below (pp. 615 and 622).

After staining the preparations were fixed in ammonium molybdate, washed in water, dehydrated in absolute alcohol and mounted in xylol dammar.

\section{OBSERVATIONS \\ Homarus vulgaris}

In the coxal region of Homarus the following nervous organs have been found: (I) receptors of the thoracico-coxal articulation; (2) receptor organ of the coxo-basipodite articulation; (3) a system of innervated elastic strands.

\section{Receptor organs in the thoracico-coxal articulation}

These receptors are present in all five peraeopods, in each of which there are two organs, a thin muscle with a special innervation and a strand of connective tissue with a number of sensory nerve cells. In the following description they will be termed the muscular and elastic receptors, respectively. These organs run side by side from their attachment on the endophragmal skeleton in the vicinity of the ganglion of the neural cord, to their insertion on the coxopodite (Text-fig. I). In the $4^{\text {th }}$ to 7 th thoracic segments, that is those of the Ist to $4^{\text {th }}$ peraeopods, the receptors originate on special projections of the endophragmal skeleton for which the term receptor rods is proposed. The rods arise close behind the ascending parts of the endosternites which, with their upper expansions, the mesophragms, form arches over the ganglionic cord and contribute to the walls of the sternal canal.

As seen in Text-fig. I, the receptor rods are curved; their lower parts are directed upwards and forwards but then bend so that their upper parts are directed up with a backward inclination. Starting with a broader base at the border of the endosternites, they diminish in thickness and become slender and flexible. In the 4 th thoracic segment the basal rigid portion is short, whereas the upper flexible part is long and has a strong backward inclination. In the following segments the rigid portions become gradually longer and the inclination of the upper parts less pronounced.

The receptor rods are enveloped by a connective tissue membrane which is continuous with the sheath of the neural cord. From the tips of the rods connective tissue strands extend upwards to the roof of the sternal canal where they blend with the membrane lining its walls; they help to keep the flexible parts of the rods straight in the position shown in Text-fig. I on the right side of the 5th segment, for when they are severed, as normally happens on dissection aimed at exposing the neural cord from the dorsal side, the rods assume the curved shape shown on the left side of the same segment. They 
straighten at once if their enveloping membrane is pulled away, as in Textfig. I in the 6th segment; this often happens unintentionally, as the connexion of the membrane to the rods is very loose and they easily slip out of it. No reference to these structures of the skeleton could be found in the literature; they are represented in one figure in the work of Milne Edwards (185I, P1. 9, fig. 3), but there is no mention of them in the text or in the explanation of figures.

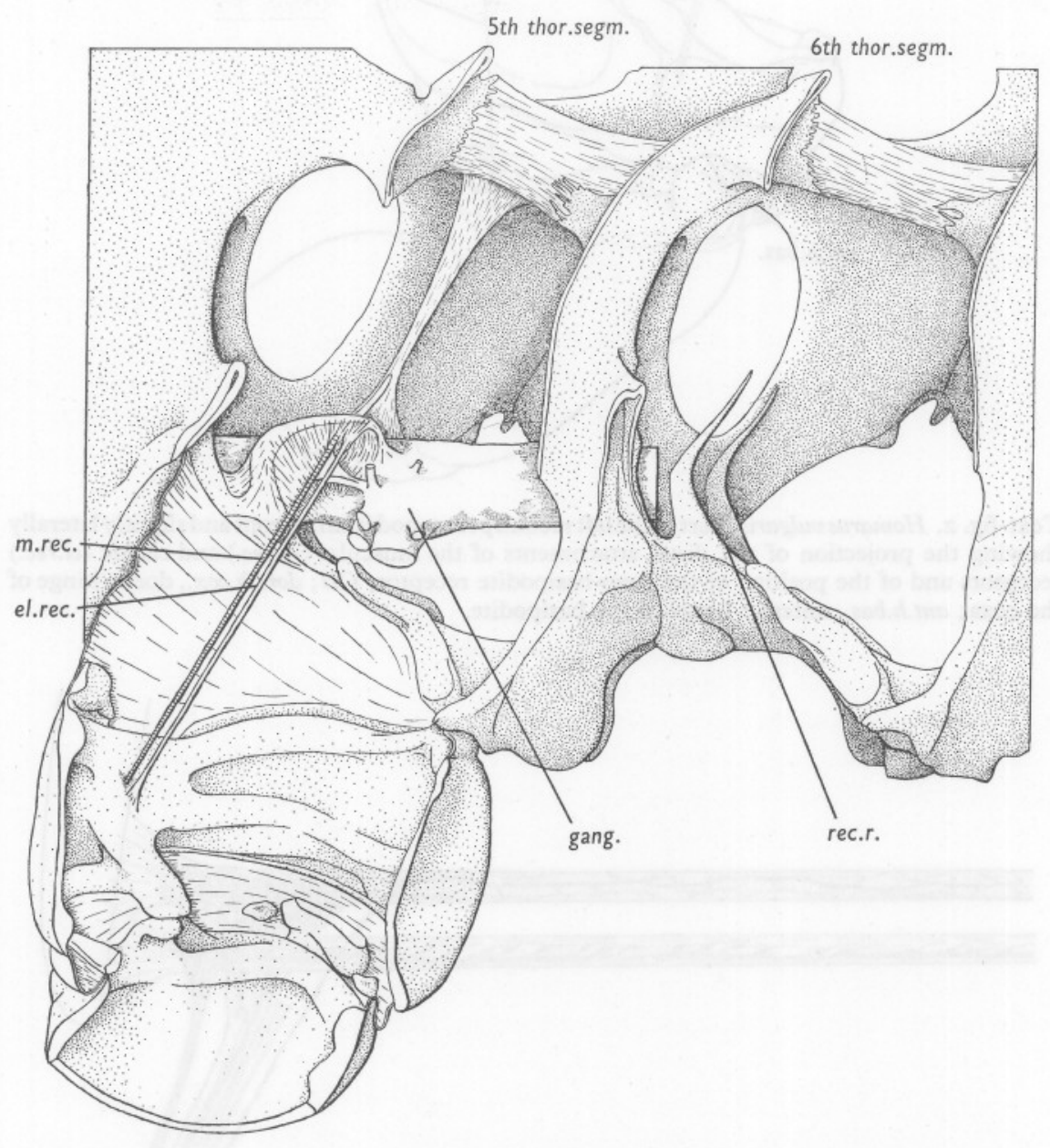

Text-fig. I. Homarus vulgaris. Parts of the 5 th and 6 th thoracic segments seen from the lateral side and slightly from behind. In the 6th segment the receptor rods, rec.r., are shown freed from connective tissue. In the 5 th segment the receptor rod of the right side is shown in its natural position, kept straight by a connective tissue strand; that of the left side is shown curved as it usually looks when exposed from above. gang., ganglion of the neural cord; m.rec., el.rec., muscular and elastic receptors of the second peraeopod. 


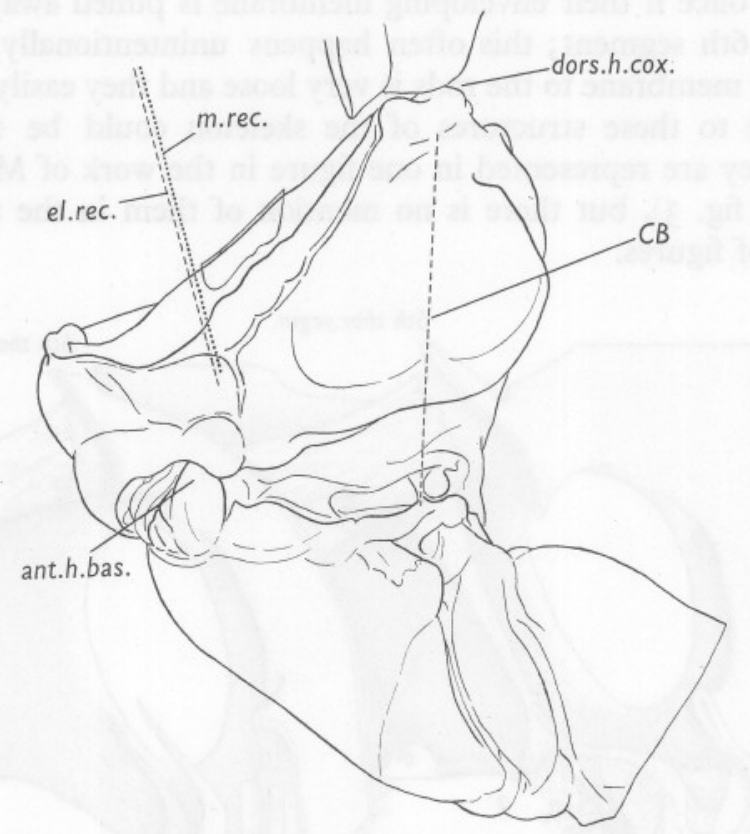

Text-fig. 2. Homarusvulgaris. Part of the left second peraeopod from in front and slightly laterally showing the projection of the distal attachments of the muscular (m.rec.) and elastic (el.rec.) receptors and of the position of the coxo-basipodite receptor, $C B$; dors.h.cox., dorsal hinge of the coxa; ant.h.bas., anterior hinge of the basipodite.

Text-fig. 3. Homarus vulgaris. Semi-diagrammatic drawing showing proximal parts of the muscular receptor (above) and the elastic receptor (below) with associated nerve elements. Nerve fibres of the additional innervated strands are drawn in dotted lines (cf. Text-fig. 5). 
The two receptors are attached to the flexible part of the rod, the elastic receptor to its tip, and the muscular one not far from it (Text-fig. 3). Near the attachment of the muscular receptor its myofibrils are replaced by connective tissue fibres which thus serve as a short tendon; these fibres and those of the elastic receptor spread fan-wise in passing into the membrane around the rod. The two receptors run from their origin to their insertion close together without having any connexions with each other. A nerve given off by a neighbouring trunk squeezes its way between the receptors, but otherwise has not any relation with either of them. ${ }^{1}$

The distal attachments of the two receptors are not at the same spot. The point of insertion of the muscle on the coxopodite can best be determined in relation to the anterior hinge of the basipodite. If an imaginary line parallel to the axis of the leg be drawn through this hinge, the point of insertion of the receptor muscle would be found a little laterally to this line, and nearer to the proximal than the distal border of the coxopodite. On the inner surface of the coxa there is often a small depression marking this spot, the position of which, projected on to the outside, is shown in Text-fig. 2. It should be noted that here the muscle tissue of the receptor extends up to the cuticle. The elastic receptor inserts a little farther distally and medially from this point; its fibres pass into the membranous tissue of the dermis and since they diverge and blend with this membrane their exact endings cannot be defined as well as that of the muscle.

In their proximal parts the two receptors are of nearly the same calibre, measuring in middle-sized specimens about $90 \mu$. The elastic receptor is of about the same thickness all along its length except at the very end, whereas the muscular one becomes gradually thicker distally.

In the 8th thoracic segment, where no special receptor rod is present, the two receptors originate on the pillar of the endosternite. Otherwise they exhibit the same features, a slight difference being that the elastic receptor is comparatively longer, so that its insertion is more distal.

\section{Structure of the muscular receptor}

The muscular receptor is composed of bundles of myofibrils with a small amount of connective tissue between them; stronger connective tissue fibres run longitudinally on its periphery. The cross-striation of the myofibrils is

1 This nerve, which arises from a trunk distributing its branches in the coxopodite, is peculiar in that it consists of bipolar nerve cells and their processes. The cells, which differ in their staining properties from the sensory elements of the receptors, are scattered along the nerve with two accumulations, one near the ganglion and the other at the diaphragm of the fracture plane of the leg. It is on this diaphragm that the distal cell processes, or at least the majority of them, end. Similar ganglionated trunks have been observed in Palinurus and in crabs. The occurrence of a nerve of such unusual structure in this part of the body suggests that it might play some role in the regeneration of an autotomized limb. Another interesting feature observed is the presence of a plexus of fine nerve fibres in the sheaths of the main trunks arising from the ganglion. 
somewhat finer than in the neighbouring ordinary muscles, being of a similar type to that of one of the muscles (RMI) of the abdominal receptor organs (Alexandrowicz, I951).

A broad bundle of nerve trunks extends between the ganglion and the muscular receptor (Text-fig. 3, Pl. I, figs. I-4). Two sorts of nerve fibres can be distinguished: (I) motor fibres innervating the muscle tissue, and (2) fibres ending at the proximal end of the receptor in its tendinous region. The former run down alongside the muscle giving off branches which penetrate between the myofibril bundles, subdividing to supply the bundles abundantly up to the distal end of the muscle. This innervation has the same characteristic pattern as in all other muscle receptors, which is a great help in locating these organs among ordinary muscles.

The fibres ending in the tendinous region appear to be of two kinds. Most of them are given off by two stout main fibres which as they approach the receptor divide into a variable number of unusually thick branches; each of these breaks up into numerous arborizations which penetrate between the fibres of the tendon. Considering the thickness of the main trunks and the density of their ramifications it appears that the amount of nerve substance is here greater than that of connective tissue (Text-fig. 3; Pl. I, figs. 3, 4). Some of the nerve branches extend into the region of the connective tissue which accompanies the muscle; one or two branches may be seen running some distance along the muscle, but there is no evidence of any anatomical relation between this sort of nerve and the muscle tissue itself.

The appearance and distribution of the thick trunks in the tendinous region of the muscular receptor is much like that of the dendritic processes of the nerve cells situated near the muscle components of the receptor organs of the extensor muscles of the thorax and abdomen. In the coxal receptors, however, no cells are present near the muscle. Consequently, the cells emitting these trunks must be situated in the ganglion of the neural cord, and, as there can be no reasonable doubt about the sensory nature of the fibres terminating in the tendon, they must be regarded as dendritic processes of receptor neurons.

The exact situation of the cell bodies of these neurons has not been established. The main difficulty is that the cells in the ganglion take a much longer time to stain with methylene blue than the fibres on the receptor, and when the latter are fading out their tracing up to their cells becomes uncertain. This obstacle might perhaps be more easily overcome in some other species.

Among the thick fibres reaching the receptor some others of a much finer calibre have been observed, which are presumably of a different kind. The number of these accessory fibres is uncertain, and as regards their destination it can only be said that they pass into the entanglements of the terminations of the thicker nerves. 


\section{Structure of the elastic receptor}

The elastic receptor consists of longitudinally directed fibres forming a tube in which a row of nerve cells and their processes are included. The fibres have elastic properties, but must be made of some substance other than the elastin of vertebrate tissues, for they do not show a specific affinity to orcein or to Weigert's resorcin fuchsin. Stained with Azan they appear brilliant red, and so, in sections through their proximal attachments, stand out well against the blue-stained tissue of the membrane enveloping the receptor rods. They can be stained with iron haematoxylin and, more selectively, with Gomori's method. The latter proved useful for obtaining a contrasting coloration of these fibres and the muscle tissue. It should be noted that the fibres on the periphery of the receptor muscle, and in other organs described below, show the same staining reaction.

The nerve cells form a row which extends almost the whole length of the receptor. They are all bipolar in shape but vary in their dimensions. The largest are situated near the proximal end of the receptor, where some may lie outside the strand. The size of the cells diminishes towards the distal end of the strand; finally they become so small that often there is doubt whether a swelling of the nerve fibre is a cell or a bead-like artifact. It is for this reason, and also because not all the cells in the tube stain equally well, that their number is uncertain; it appears to exceed fifty, but may be considerably greater. The distal processes of the cells, which are often of a wavy appearance, are applied to the fibres of the strand and evidently become attached to them, as they all keep the same direction parallel to the axis of the organ. If the axis of a cell body is not in line with its process, the latter, in order to become adjusted to the longitudinal direction of the elastic fibres, turns at an angle which, at the proximal end of the cell row, can even be acute.

The distal processes can be followed for a distance of about two or three lengths of the cell bodies, at which point the methylene-blue coloration usually stops. In some preparations a finer prolongation beyond this point may be noticed, but it is doubtful whether it is to be regarded as consisting of nervous substance. The proximal cell processes, the axons, run as a bundle alongside the cell row, enclosed within the same tube of elastic fibres. As each cell adds its axon to it, this bundle becomes thicker proximally. Coming out of the receptor, the nerve bundle runs towards the ganglion near to that of the muscular receptor (P1. I, fig. 2).

\section{The receptor of the coxo-basipodite articulation}

The receptor of the coxo-basipodite articulation belongs to the system of similar organs occurring in all joints of the peraeopods of decapods, from the coxopodite downwards. It consists, as do all others of this system, of a connective tissue strand and a row of bipolar nerve cells. It is situated on the 
triangular plate of the coxopodite, the apex of which is the dorsal hinge articulating with the thoracic skeleton. The connective tissue fibres of the receptor originate near this hinge and run downwards to the rim of the basipodite near the insertion of the $\mathrm{m}$. levator basipoditis, that is, at a point about halfway between the anterior and posterior hinges of the basipodite. The position of this point projected on to the outside of the leg is shown in Text-fig. 2.

The row of nerve cells begins at a certain distance from the proximal end of the organ; numerous nerve cells are accumulated here, many of them lying outside the strand (P1. I, fig. 6). Farther distally they form a more regular row and become gradually smaller until they are minute. In the proximal accumulation both larger and smaller elements are present, but they are never as small as those at the distal end of the strand. The distal processes of the cells are applied to the fibres of the strand in the same way as in the elastic receptor previously described. In short, the structure of these organs is fundamentally the same, the difference in the appearance of the coxo-basipodite receptor being due only to features of secondary importance such as the less regular arrangement of its fibres and of the nerve cells.

Owing to the shape of the coxopodite its dorsal hinge is situated more proximally than the point of insertion of the two receptors of the thoracicocoxal articulation, which consequently extend distally beyond the point of origin of the coxo-basipodite receptor. This arrangement is shown in Textfigs. 2 and 4 .

\section{The system of innervated elastic strands}

In this system which is regarded as constituting the receptor elements of $\mathrm{m}$. levator basipoditis and $\mathrm{m}$. depressor basipoditis the following parts can be distinguished: (I) a stronger non-innervated strand which will be referred to as suspensory ligament, (2) the main innervated strands, and (3) the additional innervated strands (Text-figs. 4 and 5).

\section{Suspensory ligament}

The suspensory ligament is a flat band of connective tissue which extends from underneath the neural cord towards the dorsal hinge of the coxopodite, dividing into branches which insert on several points situated at various distances from the hinge. The mesial part of the ligament is continuous with a membrane lying under the ganglion, which has a firm attachment to the borders of the endosternite, at the place where the short heads of the $\mathrm{m}$. levator and $\mathrm{m}$. depressor basipoditis originate. ${ }^{1}$ From this point the suspensory

\footnotetext{
1 These portions of the named muscles are situated beneath the main nerve trunks arising from the ganglion. According to Schmidt (1915) they originate, in Astacus, at the proximal border of the coxopodite. In Homarus their line of attachment has beenfoundmore proximally, along the border of the endosternite. The nomenclature of these and other muscles mentioned in this paper is that of Schmidt, which has also been adopted by Cochran (r935) and by Balss (I94I).
} 


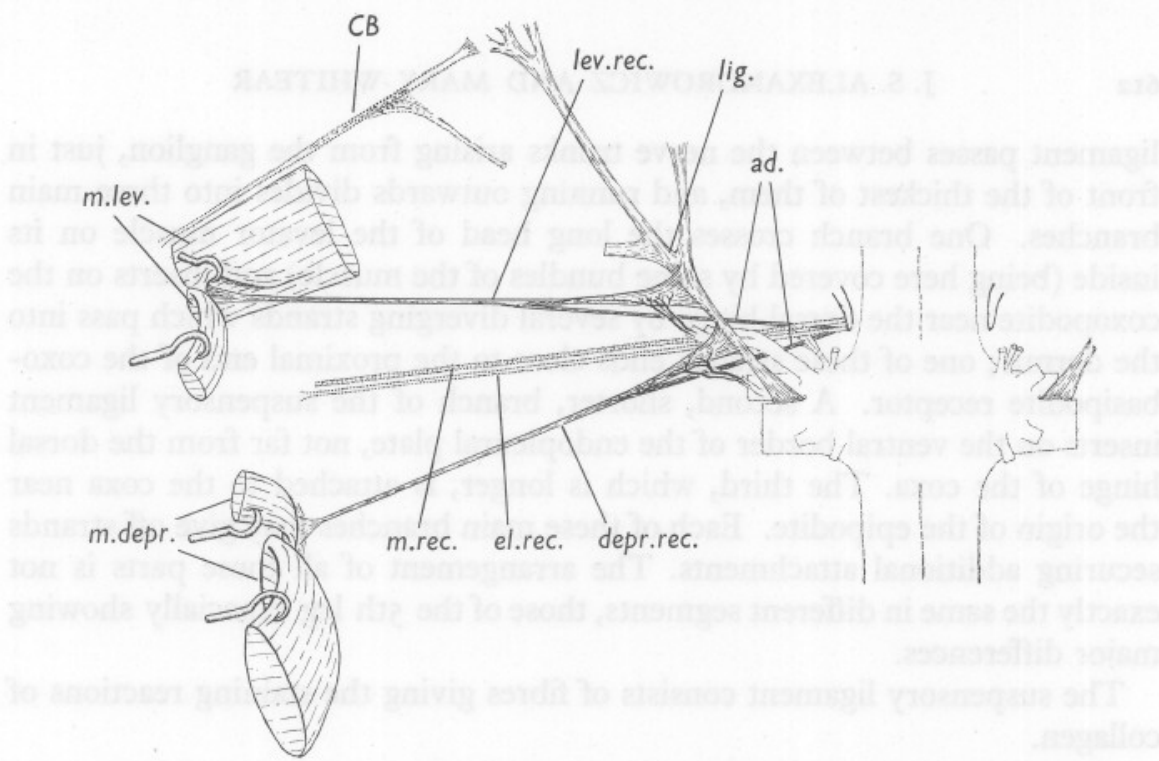

Text-fig. 4. Homarus vulgaris. Topography of the system of innervated elastic strands in relation to other receptors in the coxa. The elements represented as if lying in one plane are in the animal body arranged in a cylindrical fashion, those seen in the upper part of the figure being approximately opposite to those in the lower part; besides, the axis of the coxa is almost perpendicular to the horizontal plane of the neural cord. lig., suspensory ligament; lev.rec., depr.rec., levator and depressor receptors; m.rec., el.rec., muscular and elastic receptors; $C B$, coxo-basipodite receptor; m.lev., m.depr., parts of the levator and depressor muscles; ad., additional innervated strands.

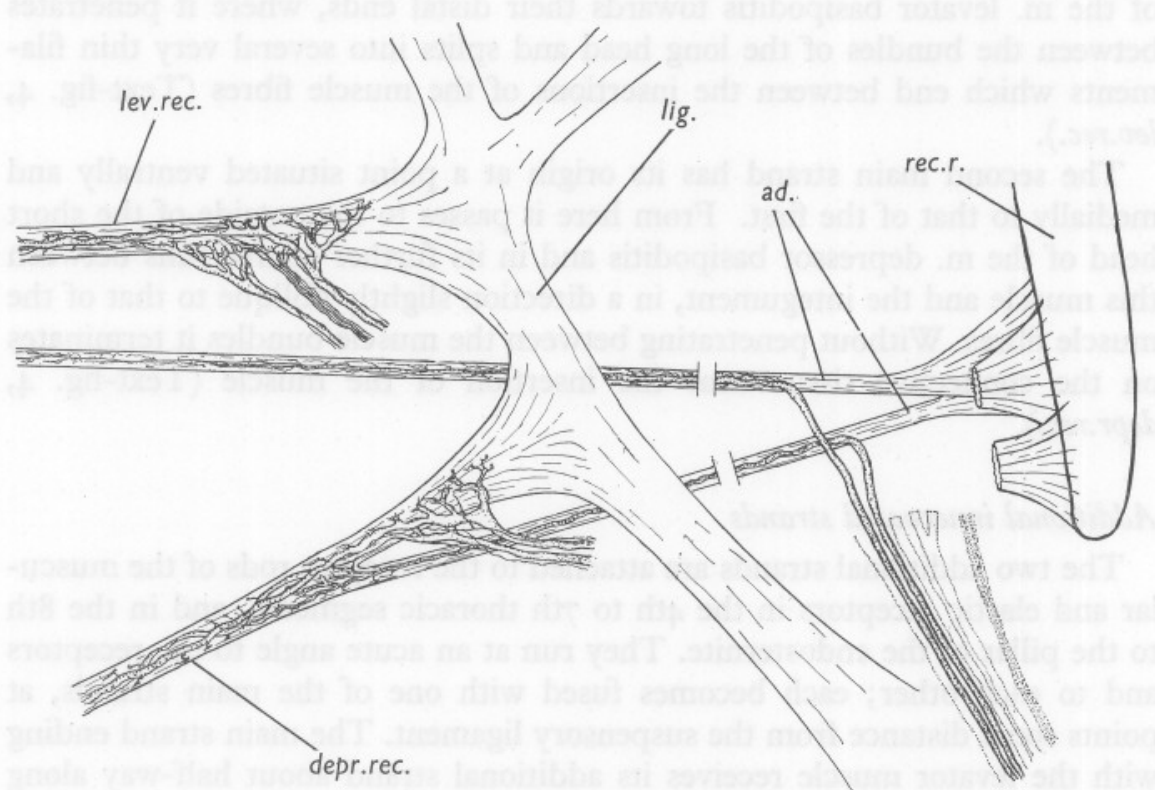

Text-fig. 5. Homarus vulgaris. Nerves of the levator and depressor receptors; same lettering as above. Note the difference in the innervation of each strand. The muscular and elastic receptors are cut away near their origin at the receptor rod (rec.r.) (cf. Text-fig. 3). 
ligament passes between the nerve trunks arising from the ganglion, just in front of the thickest of them, and running outwards divides into three main branches. One branch crosses the long head of the levator muscle on its inside (being here covered by some bundles of the muscle) and inserts on the coxopodite near the dorsal hinge by several diverging strands which pass into the dermis; one of these strands ends close to the proximal end of the coxobasipodite receptor. A second, shorter, branch of the suspensory ligament inserts on the ventral border of the endopleural plate, not far from the dorsal hinge of the coxa. The third, which is longer, is attached to the coxa near the origin of the epipodite. Each of these main branches may give off strands securing additional attachments. The arrangement of all these parts is not exactly the same in different segments, those of the 5 th leg especially showing major differences.

The suspensory ligament consists of fibres giving the staining reactions of collagen.

\section{Main innervated strands}

There are two main innervated strands connecting with the suspensory ligament by means of diverging fibres (Text-figs. 4, 5; Pl. II, fig. 7). One of the strands originates at a point on the ligament situated anteriorly to the thickest nerve trunk of the segment and runs between the short and long heads of the $\mathrm{m}$. levator basipoditis towards their distal ends, where it penetrates between the bundles of the long head and splits into several very thin filaments which end between the insertions of the muscle fibres (Text-fig. 4, lev.rec.).

The second main strand has its origin at a point situated ventrally and medially to that of the first. From here it passes to the outside of the short head of the $\mathrm{m}$. depressor basipoditis and in its further course runs between this muscle and the integument, in a direction slightly oblique to that of the muscle fibres. Without penetrating between the muscle bundles it terminates on the connective tissue near the insertion of the muscle (Text-fig. 4, depr.rec.).

\section{Additional innervated strands}

The two additional strands are attached to the receptor rods of the muscular and elastic receptors in the 4th to 7 th thoracic segments, and in the 8th to the pillar of the endosternite. They run at an acute angle to the receptors and to each other; each becomes fused with one of the main strands, at points some distance from the suspensory ligament. The main strand ending with the levator muscle receives its additional strand about half-way along its length, but the second additional strand is shorter and reaches the main depressor strand nearer the ligament (Text-fig. 4). 
The innervated strands consist of fibres of elastic properties, for they can be stretched to about twice their length and return to the original condition when the extending force is relaxed. Evidently they are made of the same substance as the fibres of the elastic receptor. In sections through the region of their attachment to the ligament, stained with Azan, the passage of the thicker red fibres of the elastic strands into the blue-stained finer elements of the ligament can be well observed.

\section{Nerves of the innervated strands}

The arrangement of the nerve fibres in the innervated strands shows particular features in each of them (Text-fig. 5).

The strand inserting at the depressor muscle, which for short is termed the depressor receptor, receives three stout fibres. Two of them come from the nerve trunk arising next in front of the thickest trunk of the leg. Along with these stout fibres run a few others, of extremely fine calibre, the number of which is difficult to determine. A third stout fibre, but not so thick as the two others, travels in the additional strand. It comes out of the ganglion with the bundle of nerves of the muscular receptor, penetrates into the additional strand and reaches the main strand near the other nerves and distally to them. All three fibres break up into numerous branches, their terminations supplying the strand in a good part of its length (P1. II, fig. 8).

The other main strand, the levator receptor, receives: (I) two stout fibres, associated with very thin ones as in the other strand; (2) a bundle of several fibres, probably six, which are much thinner, but not so thin as those accompanying the two stout ones. All these fibres are given off by the nerve trunk which originates from the ganglion with a common root with that containing the nerves to the depressor strand, but from a more dorsal division of it which carries motor and sensory nerves of the coxopodite.

The additional strand of the levator receptor receives its nerve fibre from the ganglion in the same bundle as that of the other additional strand (Textfig. 5). Penetrating into the strand, this nerve gives off many ramifications ending on the elastic fibres (P1. I, fig. 5); distally the nerve elements become gradually finer and less distinguishable. If some of them pass on to the strand they can be only very thin ones.

To sum up: both the depressor and levator receptors have a similar nerve supply of two stout fibres accompanied by very fine ones. They differ in that the depressor receptor gets a third thick fibre brought by its additional strand, whereas the levator receptor receives a bundle of thinner fibres from the same nerve trunk in which its two thick fibres are travelling. As to the additional strands, one appears only to carry a third fibre to the depressor receptor, whilst the second is an organ in its own right with nerve terminations on its elastic components. 
As regards the origin of the nerve fibres it has been noticed that the two thick fibres of the depressor strand, when followed in the proximal direction, are found at the ganglion close to the bundle containing the fibres of the muscular receptor and those of the additional strands. It is possible that the nerves of the levator strand have a similar origin, but this could not be observed directly with sufficient certainty.

Although so many nerve elements are mentioned above, the description may not yet be complete. In some cases, for instance, thin fibres have been noticed which possibly enter the additional strands with the thick ones, but they were not distinct enough to be followed.

The relation of the nerve elements to the strands is interesting in several points. One is the calibre of the nerve fibres, which is larger than is ever met with in nerves supplying a muscle bundle of comparable dimensions. Another is the tendency of even the thick nerves to penetrate between the elastic fibres of the strands and to occupy an axial position; this feature can best be observed in transverse sections. In the main strands there is a somewhat irregular intermingling of various elements, but in the additional levator strand it can clearly be seen that the elastic fibres form a tube in which the nerve fibre and its branches are enclosed.

The branches of the nerve fibres in the main strands are of various lengths and thicknesses. In the region where the main fibres enter the strand they give off many thick short branches, the ramifications of which end after a short course (Pl. II, fig. 8). The picture of their terminations in methylene-blue preparations is hazy, but from what can be seen it can be inferred that the area of distribution of each branch is small. As, however, these branches are numerous it looks as if nerve endings were present at every point of the elastic fibres, as far as the nerves reach. The thin short branches of the main trunks behave like the secondary branches of the thick ones. The long branches run down the strand and give off in their turn shorter ramifications ending near their origins and longer ones continuing the distal course. It is not quite clear how far the nerves extend in each of the strands, but it may be assumed that they occupy at least the half of their length. It has not been possible to determine whether or not each of the main fibres sends its branches as far as the others. The best preparations show such an abundance of intermingling nerves that the tracing of individual elements is uncertain.

As there are no cells between the endings of these fibres and the ganglion it is evident that the cell bodies of all these neurons lie within the central nervous system. Since there can hardly be any doubt that the innervated strands having relations with muscles are receptors of some kind, their nerves, at least the majority of them, have to be regarded as afferent fibres, being elongated dendritic processes of sensory nerve cells. The nature of the thin fibres is an open question as other interpretations are possible. 


\section{Hints on dissection}

All parts of the animal body should be cut away leaving only the ventral part of the thorax with the coxopodites and parts of the basipodites. The sternal canal should be opened from above, beginning at the posterior segments, and the parts of the endophragmal skeleton cut down to a level slightly above the dorsal hinge on the coxa. The receptor rods can now be located more or less easily depending on the size of the specimen; they appear curved as shown in Text-fig. I if the membrane enveloping them has not been damaged. To expose the muscular and the elastic receptors in their whole length it is necessary to remove a good part of the chitinous case and of the muscles of the coxa, while it is borne in mind that the receptors run almost vertically from their origin on the rods towards the anterior hinge of the basipodite; the lines of incisions should therefore run down the coxa one a little in front of its dorsal hinge, and the other on the opposite side of the leg. It is better not to try to expose the receptors at once, but to put the preparation into the staining solution, and to continue the dissection after the proximal parts of the receptors become visible. The staining is often impeded by clots of blood adhering to the receptors and other organs; the clots can be removed with a forceps and a fine scalpel, but to do this without spoiling the organs is a delicate operation. Two ways of proceeding further can be followed. The preparations can either be left in the staining solution and then fixed without removing the chitin, which goes off easily later after fixation in ammonium molybdate, or the soft parts can be detached from the chitinous cuticle at this earlier stage. In the latter case the receptor rods must be cut through first, and then all soft parts cautiously separated from the cuticle, while the muscle tendons should be cut through at their bases. Then the preparation can be spread and pinned on to a paraffin plate. This method has the advantage of permitting better observation of the staining, but the tissues are easily damaged.

To obtain preparations with the suspensory ligament and the coxo-basipodite receptor, the lateral line of incision must be made behind the dorsal hinge of the coxa. It is possible thus to get all receptor organs on one slide. For study of innervated strands it is preferable to remove the chitin during the staining because otherwise it is difficult to spot the strands and expose them in the right way.

The only certain way of finding the suspensory ligament is by tracing the innervated strands up to their origin on this ligament, but the strands cannot be practically identified until their nerves have stained. The separation of the ligament from the arteries, nerves, connective tissue strands and blood clots is difficult, and can best be performed after the preparations have been transferred into xylol.

\section{BRACHYURA}

Proprioceptors originating at the endophragmal skeleton and ending on the coxopodites have been found in all the crabs investigated, but their arrangement is not the same as in Homarus, the important difference being that the elastic receptor appears to be missing. The innervated strands are present in Cancer and in Carcinus, though forming a simpler system than that of the lobster; in Maia they could not be found as separate organs.

\section{Muscular receptor}

The muscular receptors are present in all five peraeopod segments, but only in that of the chela is there a special chitinous projection to which the 
muscle is attached and for which the term receptor rod may appropriately be used. No mention of this part of the skeleton could be found in the literature, so it will be described here.

The receptor rod is a long thin projection from that plate which limits the 4th thoracic segment anteriorly, and which is called the second endopleurite by Drach (1939). ${ }^{1}$ The receptor rod arises from the ventral border of this plate, laterally to the mid-point of the border, and projects at an acute angle inwards and backwards, ending at approximately the same distance from the mid-line of the body as the inner corner of the endopleurite plate (Drach's apophyse interne) (Text-fig. 6, rec.r.). The length of the rod in examples of the three species was as follows:

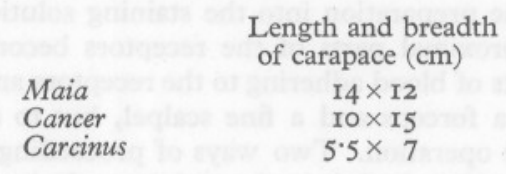

In Maia the rod is comparatively shorter; it arises at a less acute angle and its tip is situated more behind and farther away from the corner of the endopleural plate than in the other species. The tip of the receptor rod is attached by feeble connective tissue to the ligament extending from this corner to the next-following arthrophragm. The point of attachment lies about half-way along this ligament (Text-fig. 6).

In Cancer and in Carcinus the rods project at a more acute angle from the edges of the endopleural plates, close beneath them. As the endopleural plates and the receptor rods are prolonged farther towards the mid-line of the body than in Maia, only a small distance separates the ends of the rods of the opposite sides. The ligamentous connexions between the corners of the endopleural plates of the two sides and between these plates and the endosternites are stronger than in Maia; in Carcinus there are also short muscles here.

In Maia the receptor rod is thickened at its terminal part and is slightly bent (P1. II, fig. Io). In Carcinus it may be almost straight as in Maia, or there may be a more pronounced bend at the tip (Pl. II, fig. 9). In Cancer the rod curves and tapers into a point. In all these crabs the muscular receptor originates near the tip of the rod and runs at an acute angle to it to

1 Pearson, in his monograph of Cancer (1908) designates this plate as the endosternite of the 8 th somite, that is, of the 4 th thoracic segment. Drach's denomination has been adopted here, although without knowledge of the development of this arthrophragm there is no certainty that the lower part of the plate in question is not derived from the lateral part of the sternum. The number (2nd) of this endopleurite is due to the fact, known since the work of Milne Edwards ( $1834, \mathrm{I} 85 \mathrm{I}$ ), that each endopleurite fuses with the endosternite of the following segment and not with that of its own. To be exact, they do not fuse directly but join to form a horizontal plate (lame de jonction of Drach). The ventral border of the 2nd endopleurite plate is free since the other part of the arthrophragm, an endosternite plate ascending from the sternum and fusing with the endopleurite plate, is here missing. 
insert on the rim of the coxa, near the ventral border of the tendon of the $\mathrm{m}$. promotor coxopoditis; in its course it passes on the ventral side of this muscle, between it and the $\mathrm{m}$. depressor basipoditis.

In the 5 th to 8 th thoracic segments, in which no receptor rods are present, the muscular receptors originate directly on the posterior surface of the endosternites close to their mesial border at a level higher than that of

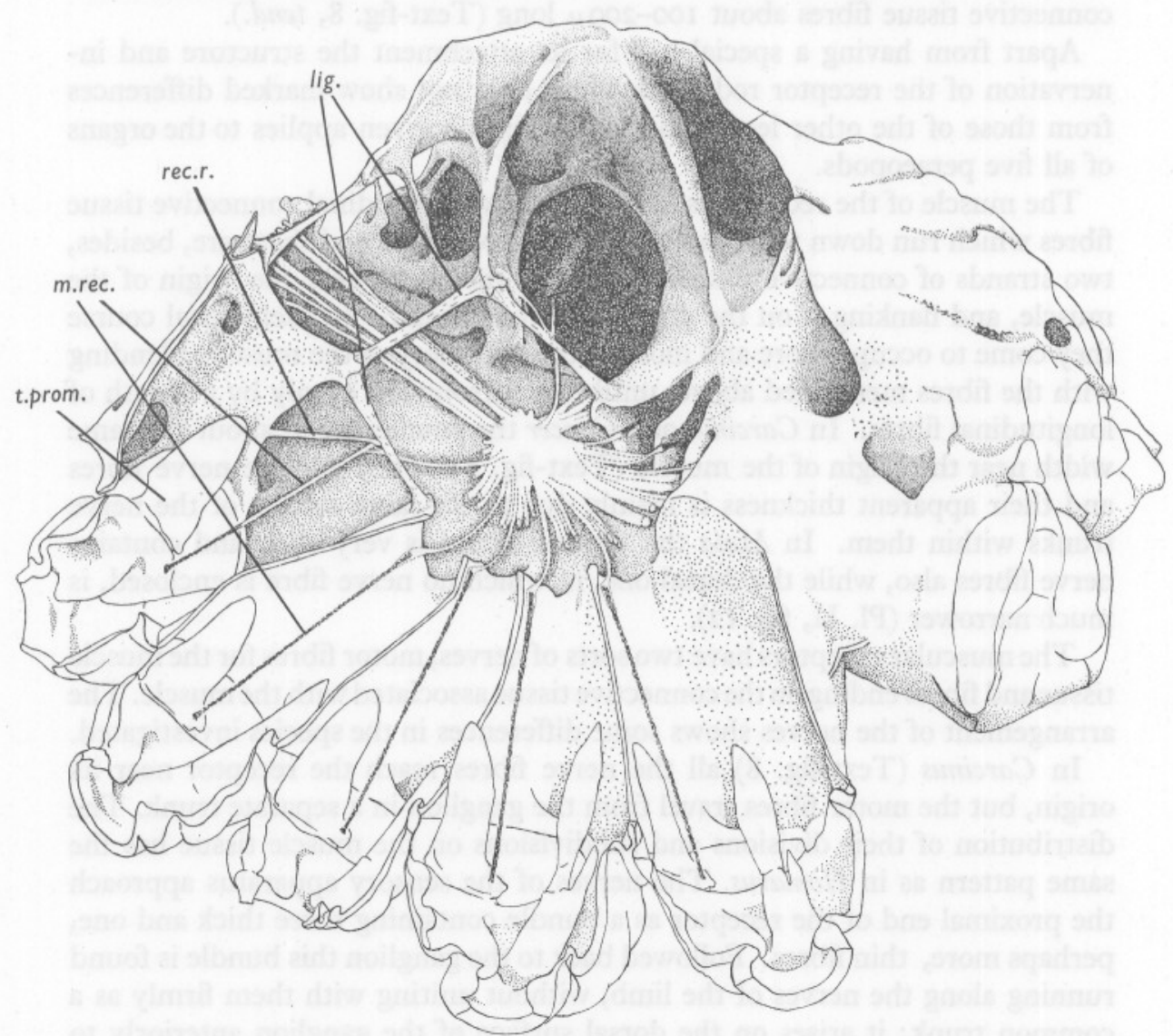

Text-fig. 6. Maia squinado. Endophragmal skeleton with parts of the peraeopods dissected on the left side to show the muscular receptors (m.rec.). rec.r., receptor rod; t.prom., tendon of $\mathrm{m}$. promotor coxopoditis; lig., ligaments of the 2 nd endopleurite.

the dorsal surface of the ganglionic mass (Text-fig. 6). From this point of attachment the receptor in each segment runs between the promotor and depressor muscles on the posterior surface of the endosternite, being separated from the chitin of this plate only by a thin layer of the fibres of the m. promotor (Text-fig. 7).

The distal attachments of the receptors in the 2nd to 5 th peraeopods are 
not exactly at the same points in various species. In Cancer they insert, as in the chela, on the rim of the coxa close to the base of the promotor tendon, but in Maia and Carcinus they insert in the base of the tendon itself. The arrangement of the receptors in Maia is shown in Text-fig. 6. At the distal insertion the muscle tissue extends up to the chitin, but at the proximal end of the receptor its myofibril bundles are fixed to the chitin by a short tendon of connective tissue fibres about I00-200 $\mu$ long (Text-fig. 8, tend.).

Apart from having a special rod for its attachment the structure and innervation of the receptor rod of the chela does not show marked differences from those of the other legs, and the description given applies to the organs of all five peraeopods.

The muscle of the receptor is surrounded by longitudinal connective tissue fibres which run down to its insertion. At its proximal end there are, besides, two strands of connective tissue attached to the chitin near the origin of the muscle, and flanking it on the dorsal and ventral side. In their distal course they come to occupy more and more of the periphery of the muscle, blending with the fibres mentioned above, until it is surrounded evenly by a sheath of longitudinal fibres. In Carcinus and Cancer the strands are of about the same width near the origin of the muscle (Text-fig. 8). They enclose nerve fibres and their apparent thickness is mainly due to the large calibre of the nerve trunks within them. In Maia the ventral strand is very wide and contains nerve fibres also, while the dorsal one, in which no nerve fibre is enclosed, is much narrower (P1. II, fig. I2).

The muscular receptors have two sorts of nerves, motor fibres for the muscle tissue and fibres ending on the connective tissue associated with the muscle. The arrangement of the nerves shows some differences in the species investigated.

In Carcinus (Text-fig. 8) all the nerve fibres reach the receptor near its origin, but the motor fibres travel from the ganglion in a separate trunk. The distribution of their divisions and subdivisions on the muscle tissue has the same pattern as in Homarus. The nerves of the sensory apparatus approach the proximal end of the receptor as a bundle containing three thick and one, perhaps more, thin fibres. Followed back to the ganglion this bundle is found running along the nerves of the limb, without uniting with them firmly as a common trunk; it arises on the dorsal surface of the ganglion anteriorly to the other nerves of the same segment. In the 4 th segment it has to travel upwards to reach the muscle arising on the receptor rod.

One of the three thick fibres approaches the receptor directly opposite its end and breaks up into several stout branches which pass on to the short tendon of the muscle and supply it with dense ramifications. In methylene-blue preparations little can be seen of their finest divisions, but it can safely be assumed that they end among the elements of the tendon. One or two nerve branches can sometimes be seen extending a little farther, between the bundles of myofibrils, but no relation to the latter has been noticed. 


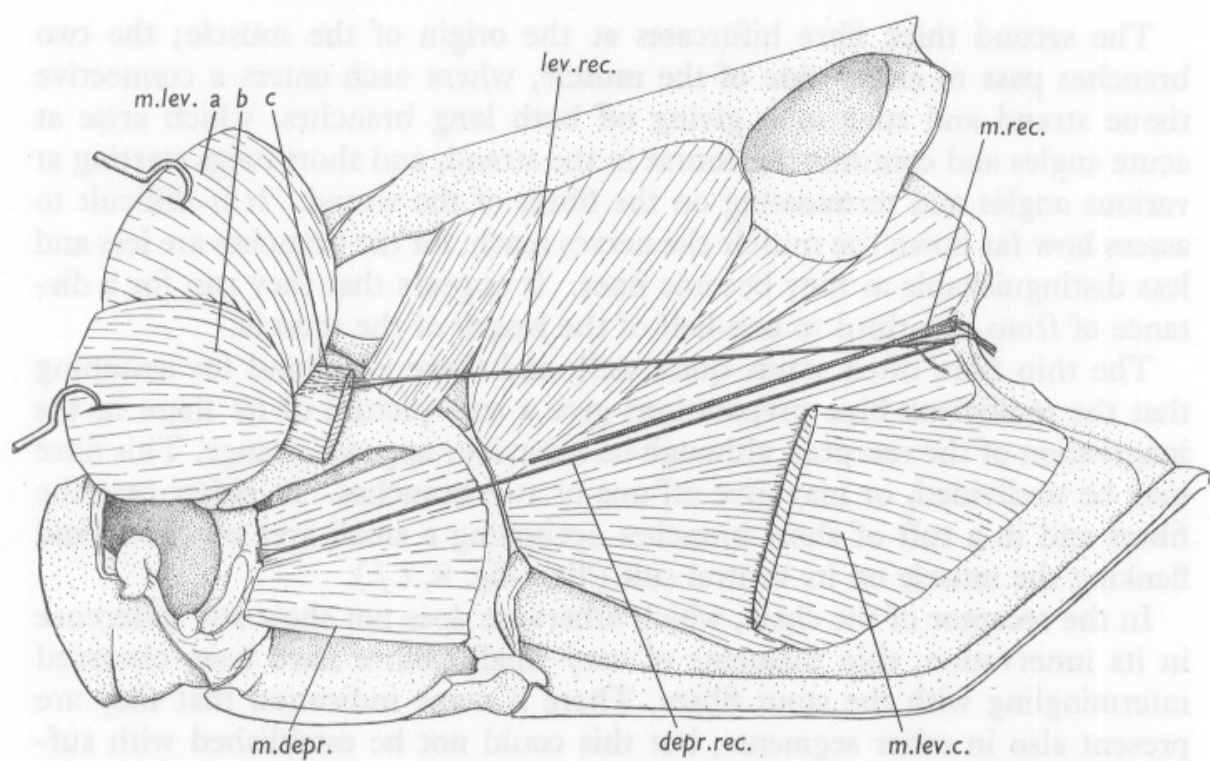

Text-fig. 7. Carcinus maenas. Posterior view of the endosternite separating the 5 th and the 6th thoracic segments of the left side with parts of the coxa and the basipodite of the 3 rd peraeopod. m.rec., muscular receptor; lev.rec., depr.rec., levator and depressor receptors; m.depr., short head of $\mathrm{m}$. depressor basipoditis; m.lev. $a, b, c$, portions of $\mathrm{m}$. levator basipoditis. The muscle bundles, the middle part of which is cut away (m.lev.c), originate, as shown in the figure, on the ventral part of the endosternite plate; they can be regarded as a branch of the strong head of the levator muscle (m.lev.b) which originates on the anterior surface of the endosternite of the next following segment (not seen in the figure).

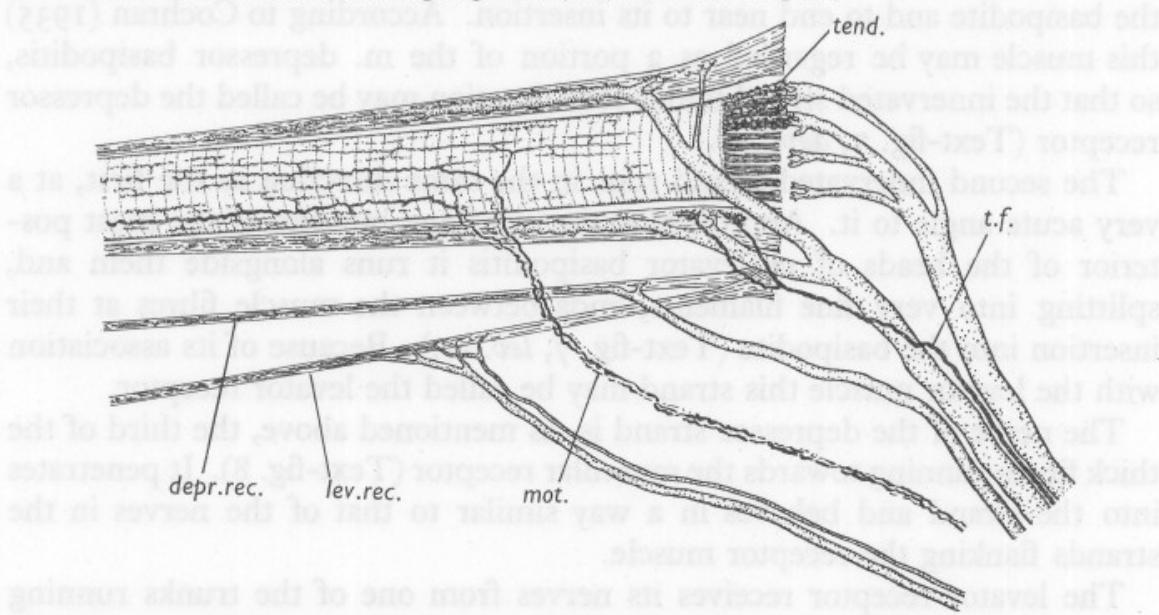

Text-fig. 8. Carcinus maenas. Proximal parts of the thoracico-coxal receptors. The semidiagrammatic representation applies to each of the 4 th to 8 th thoracic segments of the left side. The receptor muscle is seen flanked by two strands of connective tissue into which penetrate branches of a thick nerve fibre. tend., tendon of the receptor muscle; branches of the nerve fibre ending on it have been partly cut to show the fibres of the tendon drawn somewhat diagrammatically. t.f., thin fibre ending on the ventral strand; mot., motor nerves of the receptor muscle. lev.rec., depr.rec., levator and depressor receptors with their innervation. For the sake of clarity the levator depressor is drawn in a position different from that in Text-fig. 7 . 
The second thick fibre bifurcates at the origin of the muscle; the two branches pass to either side of the muscle, where each enters a connective tissue strand and runs in it giving off both long branches, which arise at acute angles and continue the course in the strand, and short twigs starting at various angles and terminating on the fibres of the strand. It is difficult to assess how far down the muscle the nerves reach, for the branches are less and less distinguishable as they become finer. It appears that they run for a distance of from one-third to one-half of the length of the muscle.

The thin fibre often stains quite well, and there is ground for assuming that the methylene-blue preparations give a true picture of its share in the innervation of the receptor, although its behaviour appears strange. This fibre may be undivided, or may give off one or two branches. In either case the fibres end in a tuft of short branches occupying a small area on the strand flanking the muscle on its ventral side (Text-fig. 8, t.f.).

In the receptor of the chela, which otherwise does not show any difference in its innervation, thin filaments of very small calibre have been observed intermingling with the stout fibres. There is some indication that they are present also in other segments, but this could not be established with sufficient certainty.

The third of the thick fibres approaching the receptor is the element of an innervated elastic strand. There are two such strands, both originating near to the proximal end of the receptor (Text-fig. 8, Pl. II, fig. II). One of them runs near and parallel to the receptor muscle, but extends farther, to become applied to the bundles of a short muscle stretching between the coxa and the basipodite and to end near to its insertion. According to Cochran (I935) this muscle may be regarded as a portion of the $\mathrm{m}$. depressor basipoditis, so that the innervated strand under consideration may be called the depressor receptor (Text-fig. 7, depr.rec.).

The second innervated strand runs in the same direction as the first, at a very acute angle to it. Approaching the overlying bundles of the most posterior of the heads of $\mathrm{m}$. levator basipoditis it runs alongside them and, splitting into very fine filaments, ends between the muscle fibres at their insertion into the basipodite (Text-fig. 7, lev.rec.). Because of its association with the levator muscle this strand may be called the levator receptor.

The nerve of the depressor strand is, as mentioned above, the third of the thick fibres running towards the muscular receptor (Text-fig. 8). It penetrates into the strand and behaves in a way similar to that of the nerves in the strands flanking the receptor muscle.

The levator receptor receives its nerves from one of the trunks running from the ganglion to the limbs. Two comparatively thick fibres reach the strand at a certain distance from its origin and give off branches which divide in their turn (Text-fig. 8, P1. II, fig. II).

Compared with the elements of the system of innervated strands in Homarus 
those in Carcinus show a simpler arrangement as there are two strands only, and the suspensory ligament is missing. As regards their innervation, however, it would be premature to draw a similar conclusion for the technical difficulties are such that other elements may yet be detected. It is also understandable that no details can be given about the behaviour of the various nerve elements in these strands, the dimensions of which may go down to Iо $\mu$ and in the thickest parts are in the range of 50-60 $\mu$.

In the 4 th thoracic segment the innervated strands originate on the receptor rods close to the attachment of the muscle and in all probability their distal insertions are the same as in other segments, but the observations have been hampered by the difficulty of obtaining preparations with these organs intact along their whole length.

In Cancer the arrangement of various receptor elements is similar to that in Carcinus. The innervated strands are also present. Cancer was less thoroughly examined than Carcinus, the latter being, despite its smaller size, more suitable for dissection.

In Maia the independence of the motor and sensory nerves of the muscular receptor is particularly manifest as the motor fibres run with the nerves of the promotor and depressor muscles, and reach the receptor at a distance from its proximal end. Two fibres at least supply the receptor, and it is interesting to note that one of these is a branch of a fibre which also supplies the promotor muscle. Reaching the receptor the motor fibres bifurcate and their branches run in opposite directions, ramifying in the usual way.

As in Carcinus, three thick and at least one thin fibre approach the receptor muscle at its origin. One of the thick fibres is destined for the short tendon and its situation is the same as previously described (P1. II, fig. I2). The two others penetrate into the connective tissue strand flanking the muscle on its ventral side and branch in this strand in the same manner as in Carcinus.

The thin fibre runs together with the thick ones. It gives off short branches, all of which appear to end on the connective tissue strand at its proximal end. This fibre did not stain so well in Maia as in Carcinus and the picture of its course was not so clear.

In the receptor of the chela the arrangement of the three thick fibres is basically the same, although at first sight it may seem to be different (P1. II, fig. I0). This is due to the fact that the two thick fibres penetrating the connective tissue strand can split into branches before reaching the receptor, and these branches enter the strand at a distance one from another. The very thin fibres running with the thick ones occur in Maia, too. They appear to associate with the thick fibre which supplies the short tendon of the muscle.

The innervated strands have not been found in Maia. It is, of course, possible that if they are in a different position they might easily be overlooked. However, the occurrence in Maia of the same number of thick nerve fibres, and the fact that one of them supplies the depressor receptor in Carcinus, gives 
probability to the supposition that the system of innervated strands in Maia has been reduced and one of its elements has become associated with the muscular receptor. A comparative study of these organs in various species of Brachyura could possibly throw some light on this problem.

In all crabs investigated a coxo-basipodite receptor, with bipolar nerve cells, is present. Owing to the different shape of the coxa in crabs, the position of this receptor is relatively more distal than in Homarus and does not come into the picture in preparations of the muscular receptor.

\section{Hints on dissection}

With crabs the main part of the dissection aimed at exposing the receptors consists in carefully cleaning away the liver; particular caution is necessary with regard to the organ in the 4 th thoracic segment where it is attached to the receptor rod.

In Maia this rod can be found more easily from the dorsal side. On removing the liver piece by piece one finds a flaccid ligament connecting the endopleurites of the opposite sides (Text-fig. 6, lig.) and this guides one to the inner corners of these plates. This region must be cleaned with care in order not to damage the other ligament running backwards from the corner of the endopleurite plate on which the tip of the receptor rod is attached.

In Carcinus and Cancer it is preferable to look for the receptor rod from below in order to find its origin on the ventral border of the 2 nd endopleurite. To make the access easier, parts of the sternum should be removed as far as possible, and the liver strands taken out. It must be realized that the receptor rod is very fragile and can be broken at a slight pull of the forceps. Its origin can be found on the border of the endopleurite plate at a point more laterally than in Maia. On moving the rod with fine forceps one can locate the point of its tip at which the receptor muscle is attached. The preparations of the rods with the receptors can be made by cutting out the rods with all the adjacent parts, i.e. muscles, nerves, remains of the liver, etc. The whole is put into methylene-blue solution and the tissues sorted out under a dissecting microscope. The rod with the receptor can be thus isolated and attached with fine pins to the paraffin plate on which it remains until the preparation is to be put into xylol.

The receptors in other segments can be stained in situ, but then only their proximal parts on the median borders of the endosternites can be made visible. For detailed study each endosternite should be cut out with parts of the coxa and the basipodite as in the preparation shown in Text-fig. 7. This is a simple matter, but there is one vulnerable point, viz. the connexion of the nerves with the receptor, and the utmost care must be taken in avoiding any pulling on these nerves. Therefore, before cutting through the sternites, it is important to sever the nerves, vessels and each strand which might tear the nerves. After the endosternite plate has been cut out it should be pinned on to a paraffin plate with its posterior surface upwards. The muscle bundles covering the receptor should be pulled aside and pinned down, but this must be done progressively. Little practice is necessary to recognize the receptor if only a small portion of it becomes stained; it can then be safely freed from overlying tissues. In every case of doubt about its further course the preparations should be put back into staining solution and examined after a while.

The innervated strand of the depressor receptor in Carcinus and Cancer, running parallel to the receptor muscle, can be found without difficulty, provided one does not cut the tissues around this muscle too freely at the beginning of the staining, because the fine innervated strand cannot then be distinguished and may be torn away. 
The levator receptor can be found by pulling cautiously aside the bundles of the levator muscle. Here again it is advisable to do this by steps, proceeding each time as far as the course of the strand can be traced and leaving the preparation in the staining solution until it is discernible.

\section{Some observations on other species}

A few observations were made with Astacus astacus, Palinurus vulgaris and Eupagurus bernhardus; in each of these the receptor organs in the coxal region have been found. Although they have not been investigated in detail, some of their features are worth mentioning since they show that the anatomy of the receptors varies in different species.

In Astacus the general arrangement of the receptors is similar to that of Homarus. Receptor rods are present in the 4 th to 8th thoracic segments; they arise from the bases of the pillars of the endosternites; in Astacus, as the sternites of these segments become progressively broader posteriorly the rods stand farther away from the nerve cord; there is no rigid connexion between the sternites of the 7 th and 8th segments, and here the rods arise, not from the hard part of the endosternite, but from the arthrodial membrane behind it. As far as they have been determined, the structure and innervation of the muscular receptor, the elastic receptor and the coxo-basipodite receptor, resemble those of Homarus. Because of the more lateral position of the rods in the hinder segments, the nerves of the receptors are correspondingly longer in these segments. The suspensory ligament and elastic strands are again similar to those of the lobster, but with differences in the details of the arrangement and innervation of the elastic strands.

In Palinurus the receptor rods are present in all five thoracic segments, but their disposition in conformity with differences in structure of the endophragmal skeleton is not the same as in Homarus. It is only in the 4 th thoracic segment that the endosternites arise near the median line of the body and have the receptor rods originating at their bases; in this segment Palinurus has long rods extending upwards and backwards as far as the roof of the sternal canal. In the 5 th to 8 th thoracic segments, in which the basal parts of the endosternites are situated at a considerable distance from the mid-line of the body, the receptor rods project from the upper parts of the endosternites, not far from the horizontal plates of the mesophragms; they originate on the posterior surface of the endosternite plates near their inner border, and are directed inwards. In all segments the rods are thin and very flexible.

The muscular receptor attaches to the rod, but the elastic receptor appears to be missing. At any rate it is not present in the immediate vicinity of the muscular one. A coxo-basipodite receptor is present. There are some strands of connective tissue which presumably correspond to the innervated elastic strands of Homarus, but their extension and connexions have not been sufficiently determined. Palinurus proved a difficult object for this kind of investigation, for in the specimens dissected there was soft yellowish tissue filling 
up the sternal canal and enveloping the outgoing nerve trunks; it made it difficult to find the receptors and prevented the stain penetrating.

In Eupagurus bernhardus the receptor rods are missing, so that the muscular receptors, the only ones which have been found, arise directly on the endosternites. They insert near the rim of the coxa.

\section{DISCUSSION}

The receptor organs described are remarkable in many respects. Not only are several of them present near to one another, but their structures show essential differences within the Decapoda. Thus in Homarus there are (I) an elastic strand with numerous nerve cells attached to it, (2) a thin muscle with a complex innervation, and (3) several elastic strands with numerous nerve fibres ending on them. In the Brachyura the organs under (I) seem to be missing in the thoracico-coxal articulation, while the muscular receptor has a more complicated structure. Both in the Brachyura and the Astacura different species show variations in the detailed arrangements of the receptors.

Several of these organs show an unusual feature in that the cell body of the receptor neuron is not situated near its peripheric endings. It is understandable that doubts may arise as to whether the observations were correct as to this point. As a rule, when the search for some nervous element has been unsuccessful, it is advisable, instead of stating that they are missing, to say that they have not been found, and, admittedly, the observations recorded in the present paper may be liable to amendments in the future. In this case, however, the histological evidence can be interpreted in only one sense, which is that the fibres terminating on the tendinous parts of the muscular receptors and on the innervated elastic strands are emitted by neurons of which the cell bodies are situated in the central nervous system. As these fibres are obviously afferent in nature the conclusion must be drawn that in the Crustacea sensory neurons can develop, as in vertebrates, a long process which behaves functionally as a dendrite, but which otherwise may be indistinguishable from an axon. In the organs under consideration various stages in the elongation of the dendrites can be observed. In the muscular receptors in Homarus the fibres of the sensory neurons differ in appearance from ordinary nerves; as they do not extend far from the ganglion there is not much difference in shape and dimensions between them and those of the receptor organs in the dorsal muscles. In the 8 th thoracic segment of Homarus, where the receptor organs originate at a greater distance from the neural cord, the dendrites of their sensory neurons are elongated and look like ordinary nerve fibres. The same is true of their aspect in crabs, and in the hinder thoracic segments in Astacus. The nerves of the innervated elastic strands have various dispositions, some, such as those of the additional strands in Homarus and of the depressor receptor in Carcinus, associate with the nerve fibres of the muscular receptor, 
while others travel in the nerve trunks of the leg, and, until their branches are seen to reach the strands, are practically indistinguishable among the ordinary fibres.

The structure of the muscular receptor in Homarus resembles in certain features that of the receptor organs in the dorsal muscles of the same animal. The aspect of the muscle and the pattern of its motor innervation appear almost identical. The connexion of the muscle and the receptor neurons is effected on the same principle, that is, the dendrites of the latter end on the connective tissue linked with the muscle but not on the muscular tissue itself. On the other hand there are important differences. One, the absence of the peripheral nerve-cell bodies has just been discussed; the other is in the position of the sensory terminations, which is at the end of the receptor muscle in the leg, but always at some distance from the attachments of the receptors in the dorsal muscles. A further difference is the presence in the coxal receptors of two sensory neurons (or even three, as in Maia) ending at the same muscle. The question arises whether there is evidence for considering them to have various functions. Their aspect in Homarus does not provide support for such a view. In crabs, however, they exhibit such differentiation in the disposition of their endings that the assumption of their having different natures has a high degree of probability.

The elastic receptor of the thoracico-coxal joint in Homarus and Astacus is so like that of the coxo-basipodite joint and the other receptors farther down the leg, that it must be considered as belonging to the same series. It is strange that it should be well developed and situated so near the muscular receptor in these animals and yet be, apparently, absent in the other species investigated.

As regards the innervated elastic strands, their very existence, in the vicinity of other receptor organs, is puzzling, apart from their structure. The ending of thick nerve fibres in elastic strands is a most unusual feature. Moreover, the levator and depressor systems receive different sets of nerves, of various kinds. It is difficult to assess how much value may be attached to these differences, but it is reasonable to assume that each anatomical difference is likely to have a functional meaning and sets a problem to be solved.

The suspensory ligament has been described as a component of the system of innervated strands and it certainly plays an important role in it. It is, however, not evident whether this is its only function. Being made of connective tissue it can only serve to offer resistance to some pulling force, but why this should be necessary in this region, apart from giving a point of attachment to the innervated strands, it is difficult to say. To the conjecture that it might give support to the ganglion it may be objected that its firm attachments are at the endosternites lateral to the median line of the body and, besides, in the 8th thoracic segment where the ligament is particularly well developed, it cannot have such a function because of the more anterior position of the ganglion. 
As stated in the introductory remarks, the occurrence of proprioceptors in the coxal articulations was predicted. The possibility of their existence was adumbrated by Bethe (1897) who, experimenting on compensatory eye movements in Carcinus maenas, expressed the view that besides the reflexes elicited by the eyes and the statocysts, a 'third factor' may play a role. Dijkgraaf $(1956 a, b)$ has demonstrated that proprioceptors must be there. They are indeed. But now the question of their function remains to be answered, for it seems most unlikely that such organs have no other role than to participate in the compensatory eye reflexes in which, as Bethe's and Dijkgraaf's experiments have shown, they play only a subordinate part.

Their number, variety and structure indicate that there is in the coxal region of decapod crustaceans a complex apparatus whose elements, or a part of them, are instrumental in registering the position of the legs with respect to the thorax. What may be the function of each of them remains to be determined.

\section{SUMMARY}

In the 4th to 8 th thoracic segments of decapod Crustacea, at the bases of the peraeopods, sensory organs of various kinds have been found. They have been observed in Homarus vulgaris, Astacus astacus, Palinurus vulgaris, Eupagurus bernhardus, Carcinus maenas, Maia squinado and described in greater detail for Homarus, Carcinus and Maia.

In all species examined there is in each peraeopod a proprioceptor consisting of a thin muscle with various nerve elements which extends from a point of the endophragmal skeleton situated near the ventral ganglia to the anteroventral part of the coxa. In the $4^{\text {th }}$ to 7 th thoracic segments of Homarus, in the 4th to 8th of Palinurus and Astacus, and in the 4th of the Brachyura, the receptor muscle is proximally attached to the tip of a chitinous projection of the endophragmal skeleton for which the term 'receptor rod' is proposed. In other instances it originates on the plate of the endosternite.

The nerve components of this 'muscular receptor' are of two sorts: (I) motor nerves spreading their branches over the whole length of the muscle, and (2) processes of the sensory neurons distributing their ramifications on the connective tissue associated with the muscle at its proximal end. The arrangement of the sensory elements is different in various species, but they all exhibit one feature, unusual in invertebrates, viz. their cell-bodies are situated within the central nervous system and not outside it.

In Homarus and Astacus there is a second receptor organ having the same attachments as the former and running close to it. It has been called 'elastic receptor' since it is composed of fibres with elastic properties; they form a sort of tube in which a row of bipolar nerve cells and their processes are enclosed. In all other species investigated this organ appears to be missing.

In all species investigated there is a sensory organ spanning the articulation between the coxa and the basipodite. It is made up of a strand of elastic 
fibres and a row of sensory nerve cells. This coxo-basipodite receptor belongs to a system of receptors of similar structure which occur in all articulations of the legs.

A different system of sensory organs consists of innervated elastic strands. As they are associated with the two muscles inserting into the basipodite they may be called the 'depressor receptor' and 'levator receptor' respectively. In Homarus and Astacus this system consists of two strands arising on the receptor rods and two others connected with a special connective tissue band termed the suspensory ligament. In Carcinus and Cancer it is simpler, being represented by two strands originating near the proximal end of the receptor muscle. In Maia these organs have not been found. The strands are abundantly supplied with nerve fibres considered to be processes of sensory nerve cells located in the central nervous system.

\section{REFERENCES}

AleXANDrowicz, J. S., 195I. Muscle receptor organs in the abdomen of Homarus vulgaris and Palinurus vulgaris. Quart. F. micr. Sci., Vol. 92, pp. 163-99.

Balss, H., I94I. Decapoda. Bronn's Tierreich, Lief 2.

Bethe, A., I897. Das Nervensystem von Carcinus maenas. I.T. I.Mitt. Arch. mikr. Anat., Bd. 50, pp. 460-546.

Cochran, D. M., I935. The skeletal musculature of the blue crab, Callinectes sapidus Rathbun. Smithsonian misc. Coll., Vol. 92, No. 9, pp. I-76.

DijKGRAAF, S., I956a. Kompensatorische Augenstieldrehungen und ihre Auslösung bei der Languste (Palinurus vulgaris). Z. vergl. Physiol., Bd. 38, pp. 49I-520.

- 1956 b. Ueber die kompensatorischen Augenstielbewegungen bei Brachyuren. Pubbl. Staz. zool. Napoli, Vol. 28, pp. 34I-58.

Drach, P., I939. Mue et cycle d'intermue chez les Crustacés Décapodes. Ann. Inst. Océanogr. Monaco, T. 19, pp. 103-391.

Milne EdWARDS, H., 1834. Histoire naturelle des Crustacés.

- I85I. Observations sur le squelette tégumentaire des Crustacés Décapodes. Ann. Sci. nat. (zool.), T. 16, pp. 222-91.

Pearson, J., 1908. Cancer. L.M.B.C. Memoirs, No. I6.

Schmid, W., I915. Die Muskulatur von Astacus fluviatilis (Potamobius astacus L.). Z. wiss. Zool., Bd. 113, pp. 165-251.

\section{EXPLANATION OF PLATES}

Plate I

All photomicrographs are made from Homarus vulgaris.

Fig. I. Receptor organs of the thoracico-coxal articulation of the 5 th thoracic segment in connexion with the ganglion seen from above. On the left side both the muscular and the elastic receptors are present; on the right side the elastic receptor is removed. rec.r., upper parts of the receptor rods cut from the endosternites.

Fig. 2. Proximal parts of the muscular (m.rec.) and the elastic (el.rec.) receptors of the right side.

Fig. 3. Muscular receptor of the right side from Fig. I under higher magnification. 
Fig. 4. Proximal part of the muscular receptor of the left side. Note its attachment to the receptor rod (rec.r.). In the bundle of nerves connecting the receptor with the ganglion are included fibres of the additional strands (cf. Text-figs. 3,5 ); the strands themselves are not seen.

Fig. 5. Proximal part of the additional strand of the levator receptor with nerve fibre branching in it.

Fig. 6. Middle part of the coxo-basipodite receptor. The axons of nerve cells are in this preparation more apart than usual; in their proximal course they unite into a compact bundle.

\section{Plate II}

Fig. 7. Homarus vulgaris. Suspensory ligament (lig.) of the right side of the 2nd thoracic segment with the main strands of the levator (lev.rec.) and depressor (depr.rec.) receptors. Additional strands are removed.

Fig. 8. H. vulgaris. Nerve fibres of the depressor receptor (cf. Text-fig. 5). ad., branches of the fibre of the additional strand; the division of the nerve fibre at a distance from the main strand, as seen in this preparation, is less common.

Fig. 9. Carcinus maenas. Receptor rod with the muscular receptor (m.rec.). The nerves are incomplete and somewhat displaced.

Fig. 10. Maia squinado. Receptor rod with the muscular receptor (m.rec.) and its nerves. $a$, fibre ending on the tendon; $b$, two fibres branching before reaching the receptor muscle; in the photograph their outlines are confluent but in fact there are two.

Fig. Ir. Carcinus maenas. Proximal part of the muscular receptor of the 8th thoracic segment of the left side. depr.rec., depressor receptor; lev.rec., levator receptor. Note the nerve fibres of the levator receptor (cf. Text-fig. 8).

Fig. 12. Maia squinado. Proximal part of the muscular receptor of the 6th segment of the left side with branches of the nerve fibre innervating the tendon and with the two nerve fibres penetrating into the strand flanking the receptor muscle. 


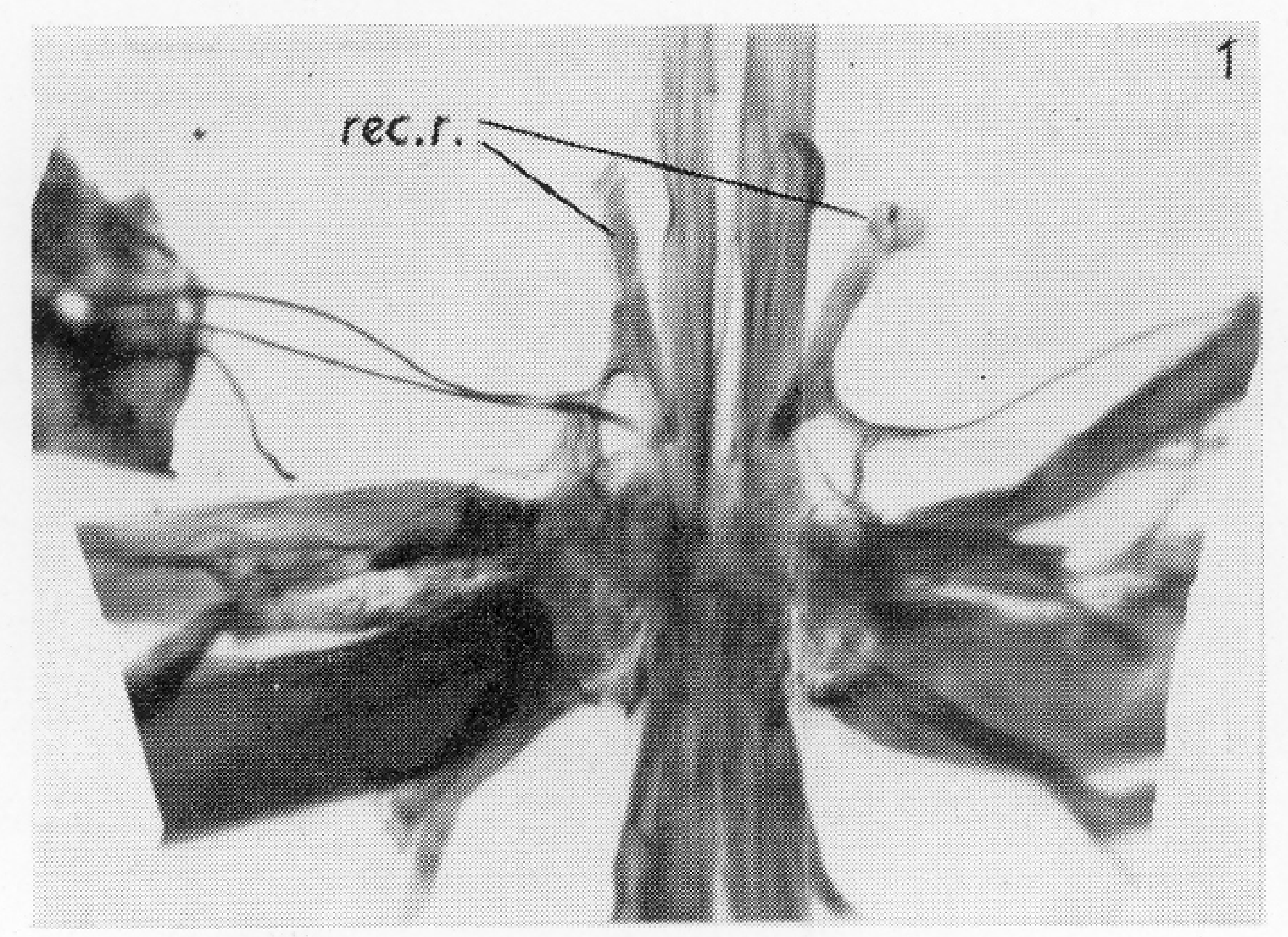

$0.5 \mathrm{~cm}$

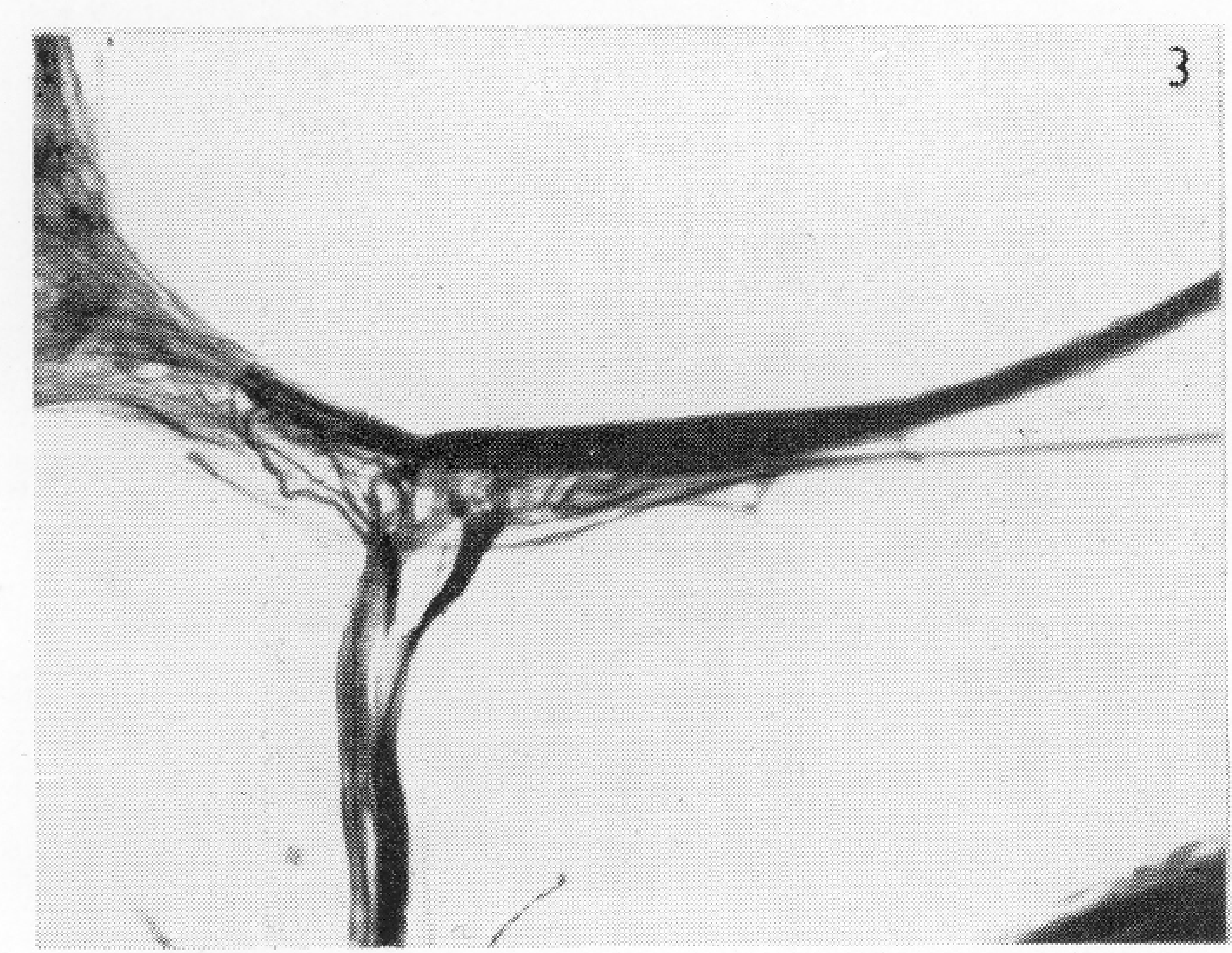

$500 \mu$

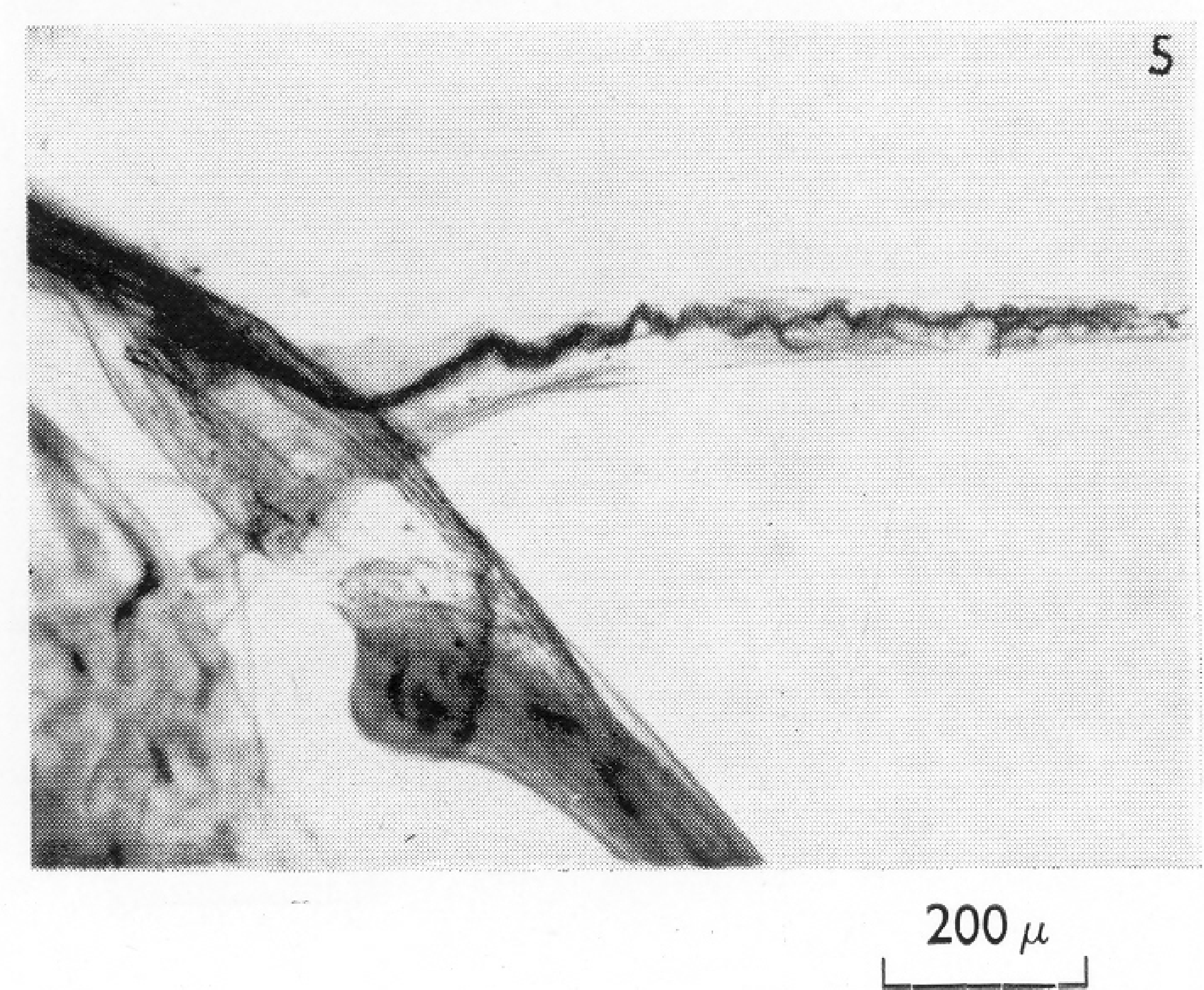

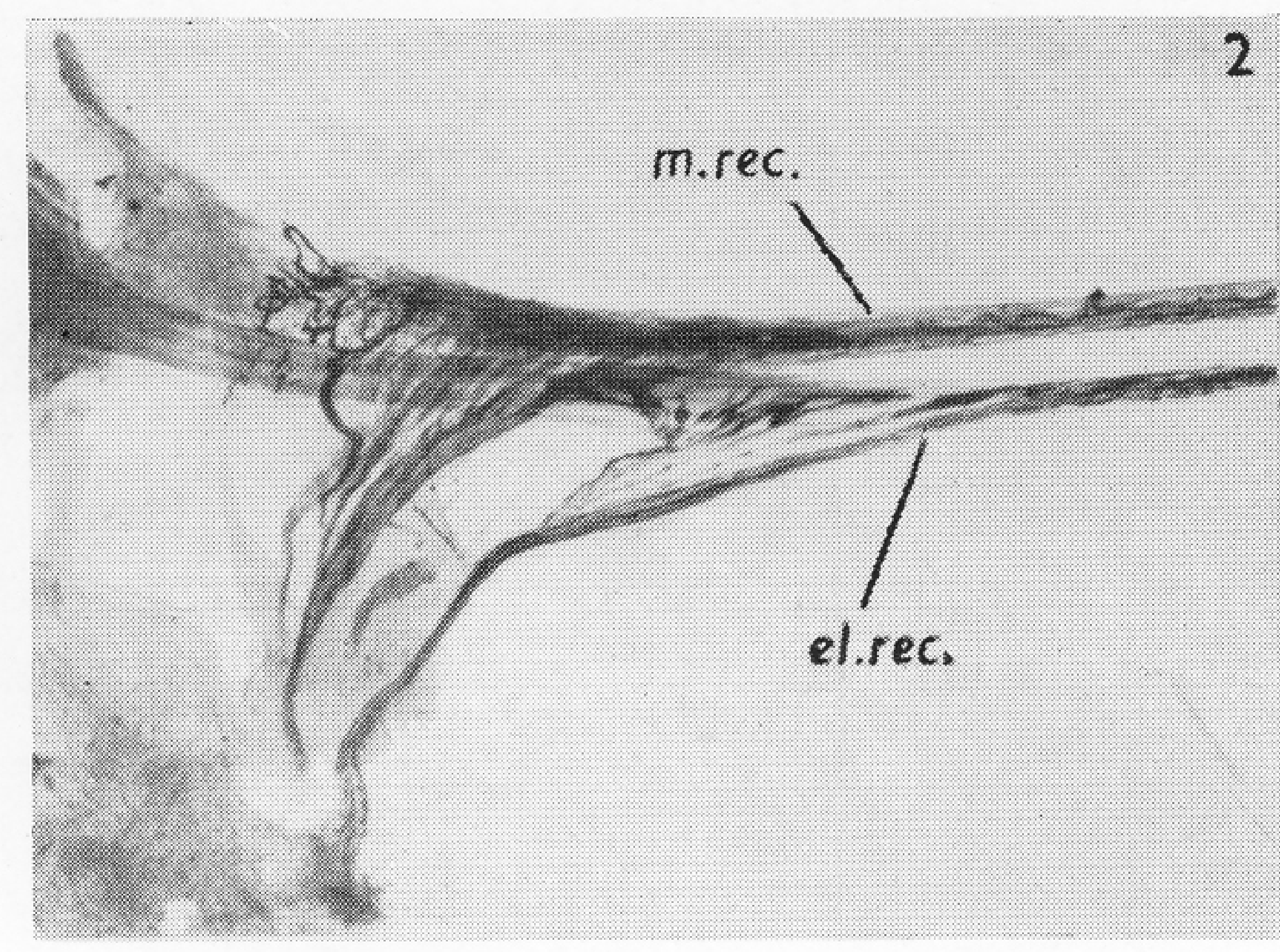

$500 \mu$

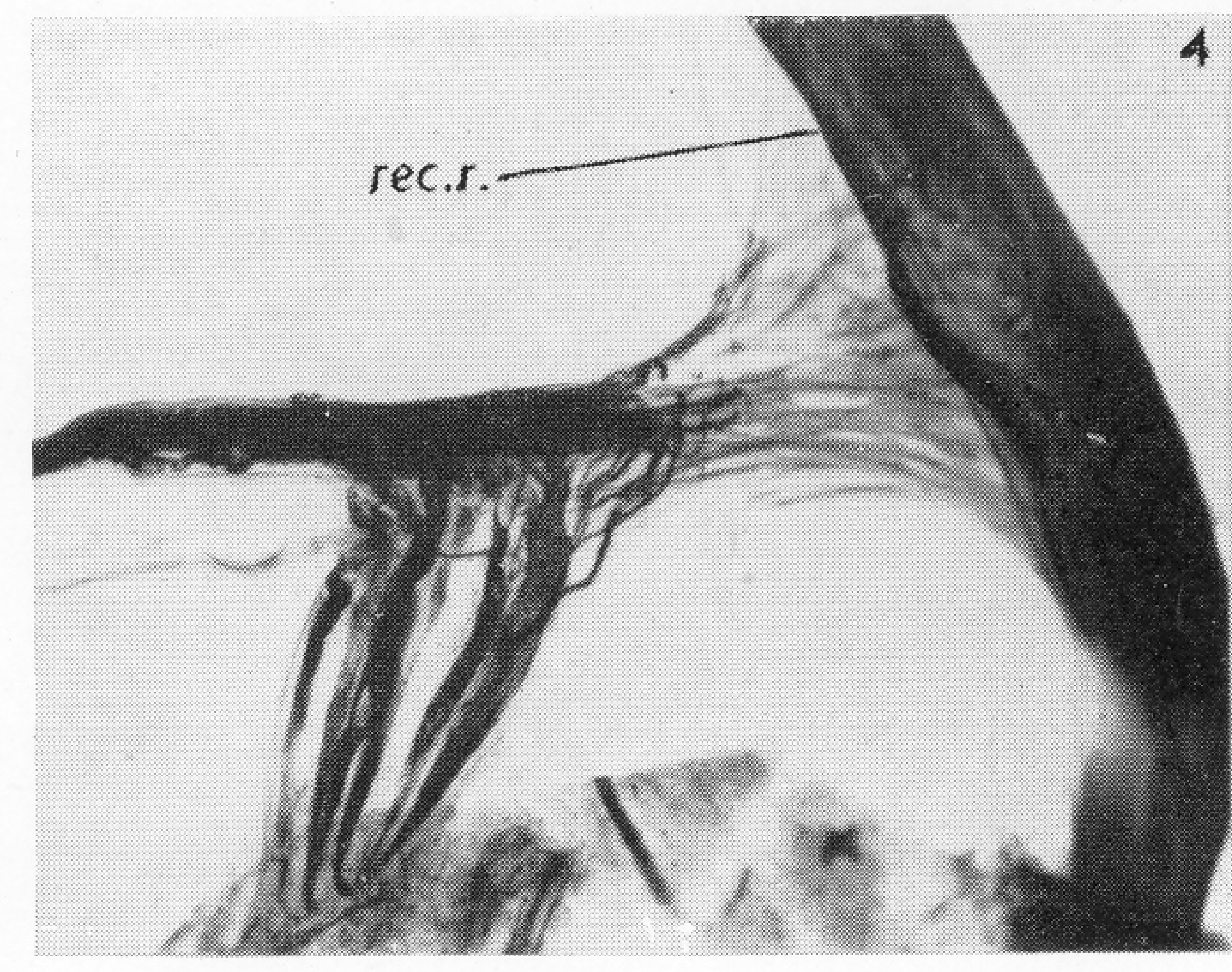

$500 \mu$

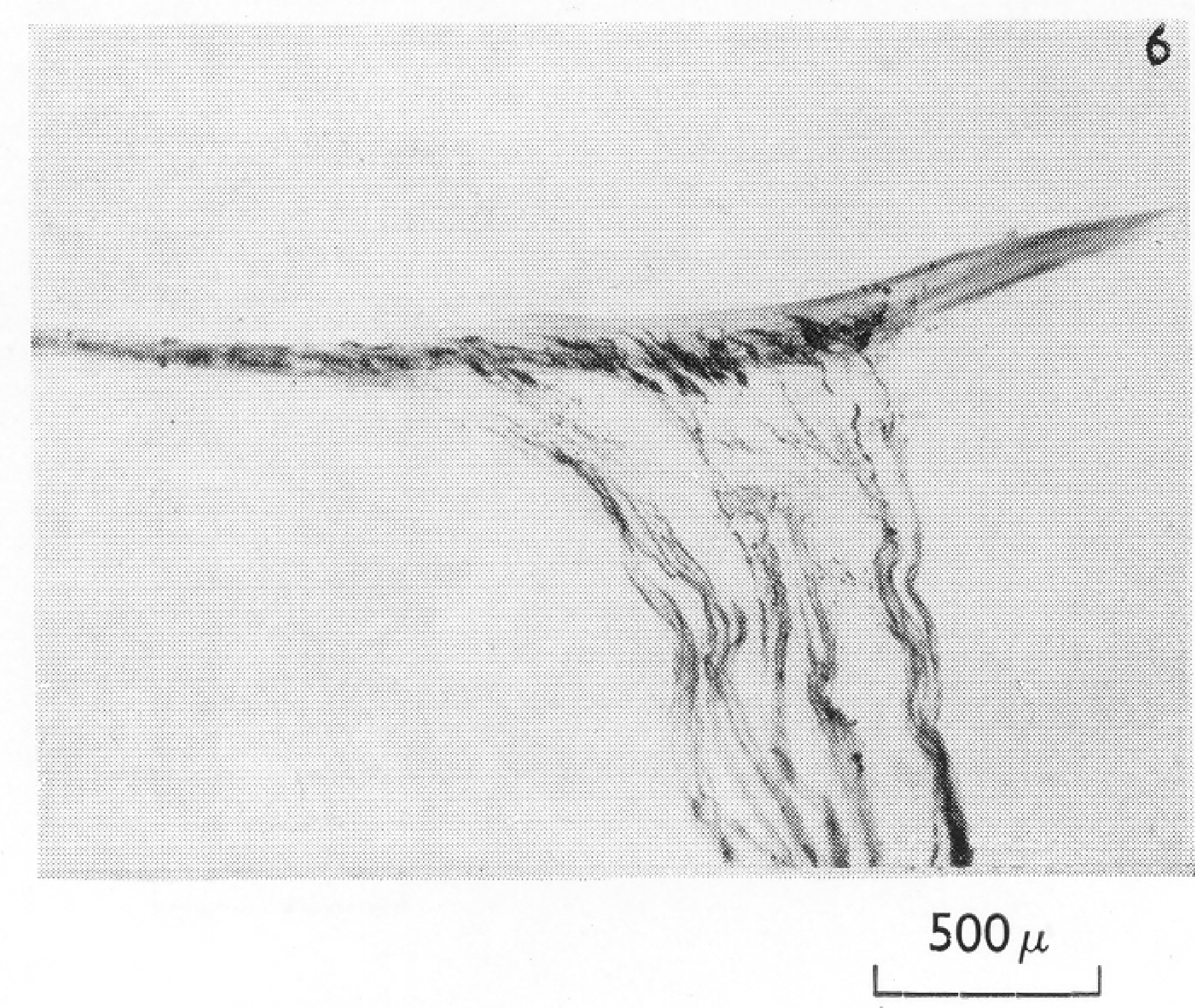

(Facing p. 628) 


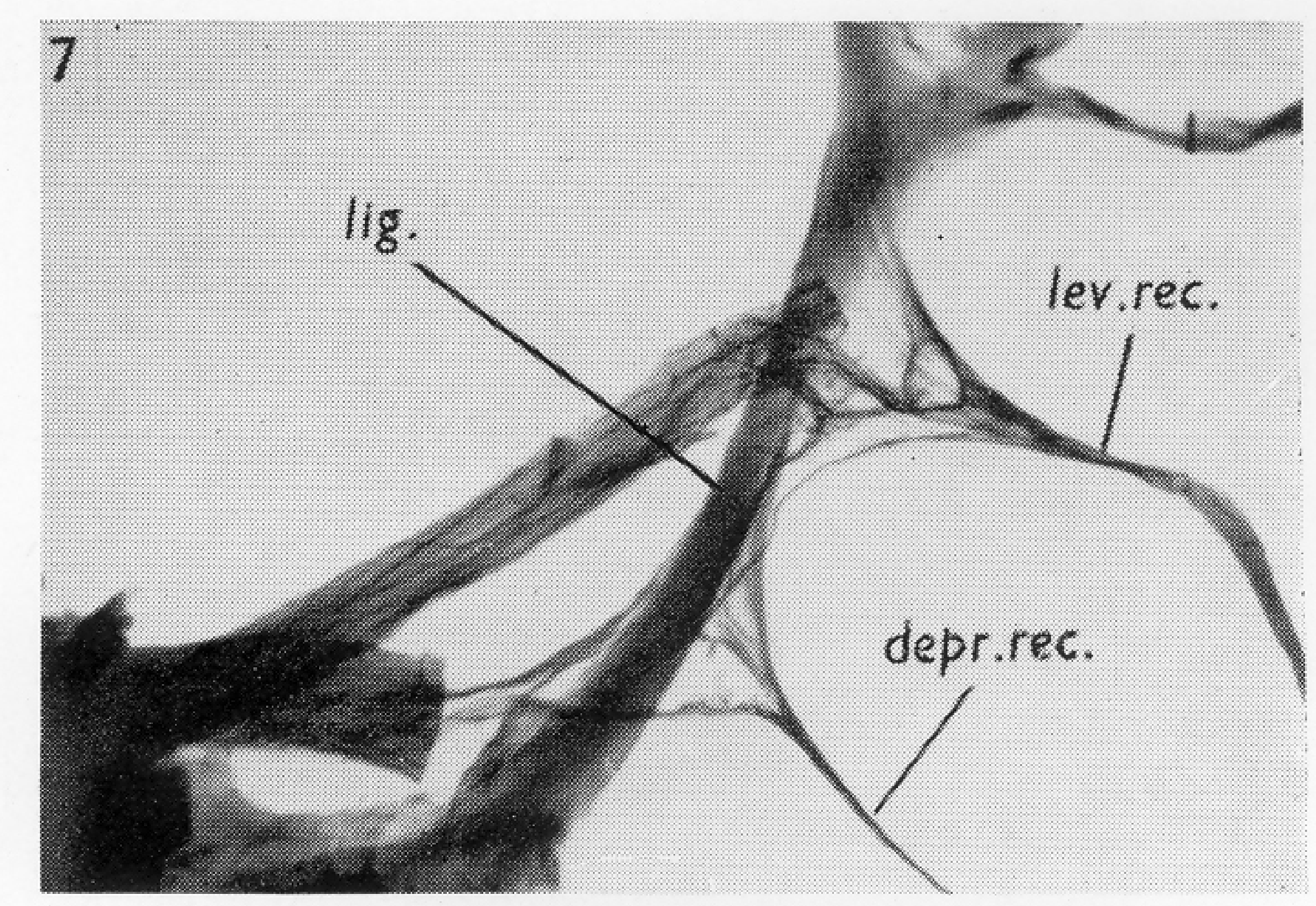

$2 \mathrm{~mm}$

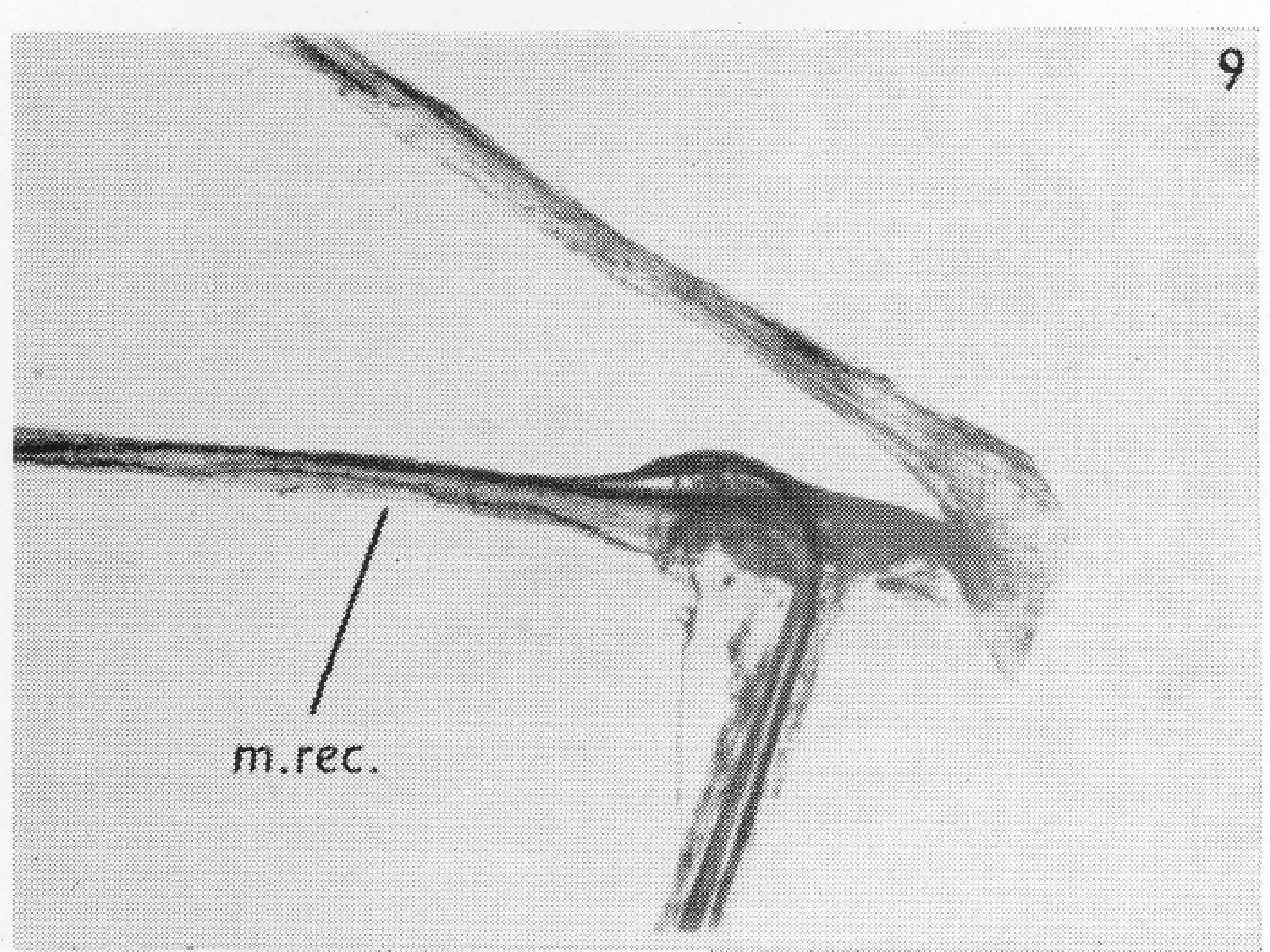

$500 \mu$

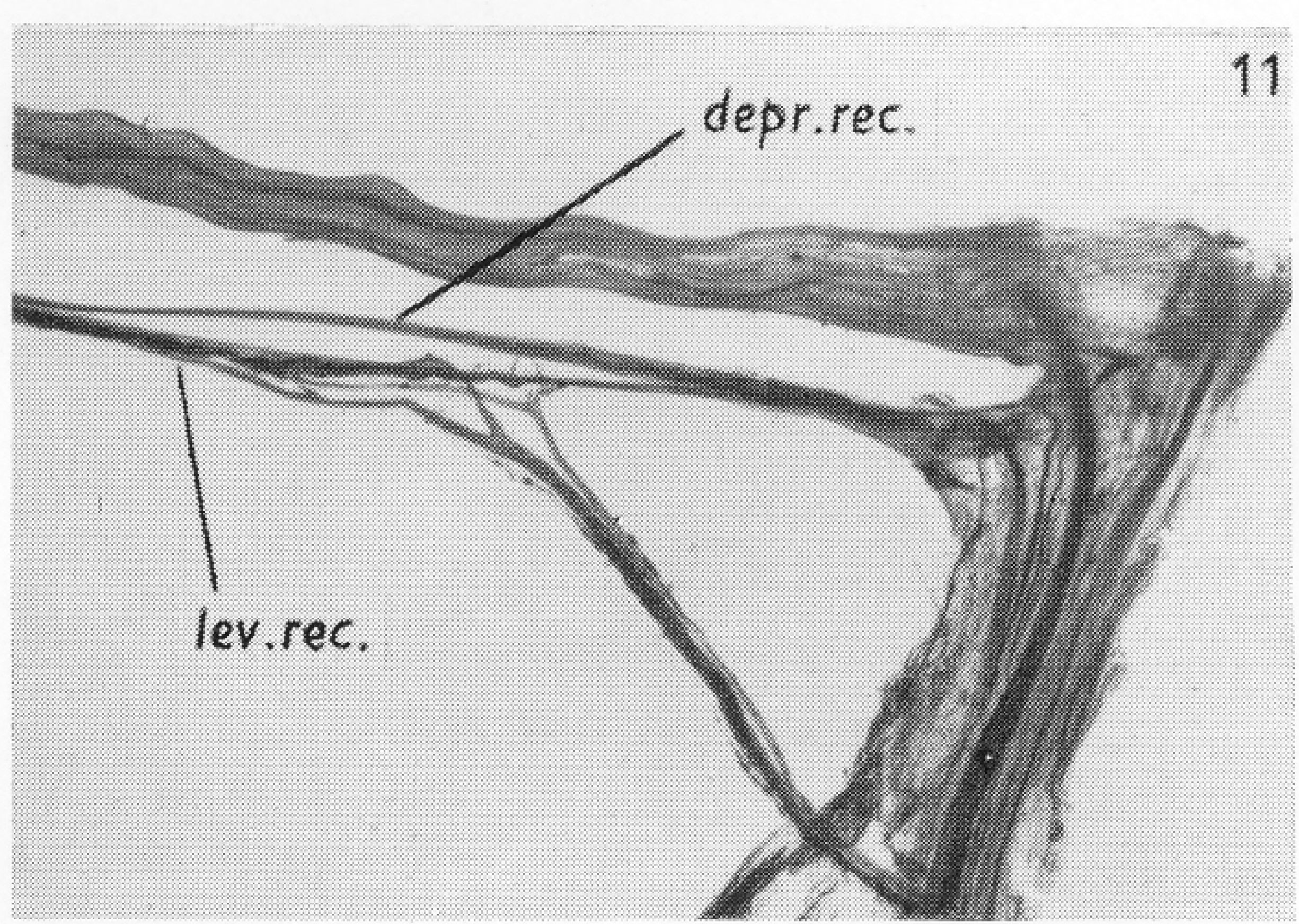

$500 \mu$

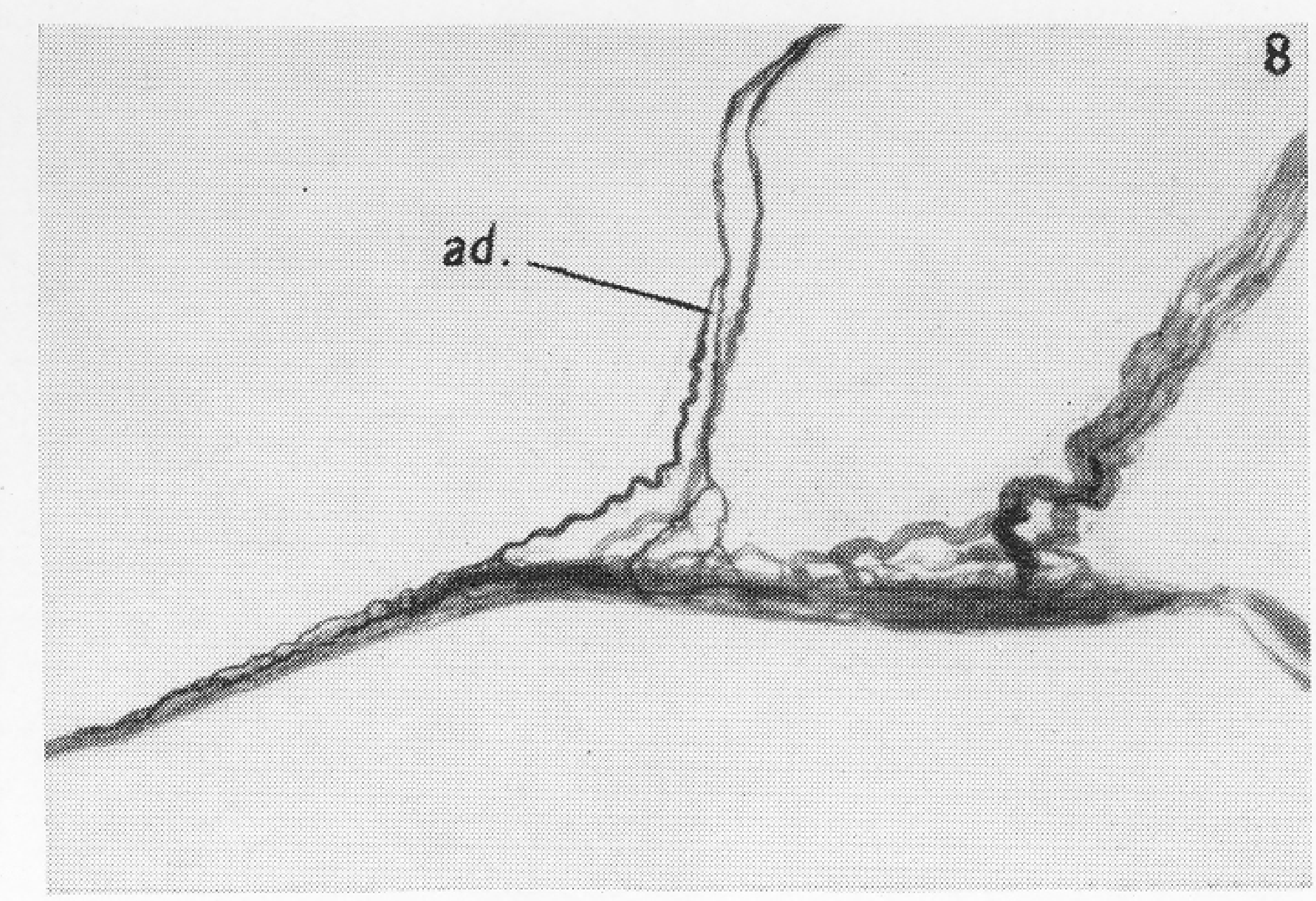

$500 \mu$

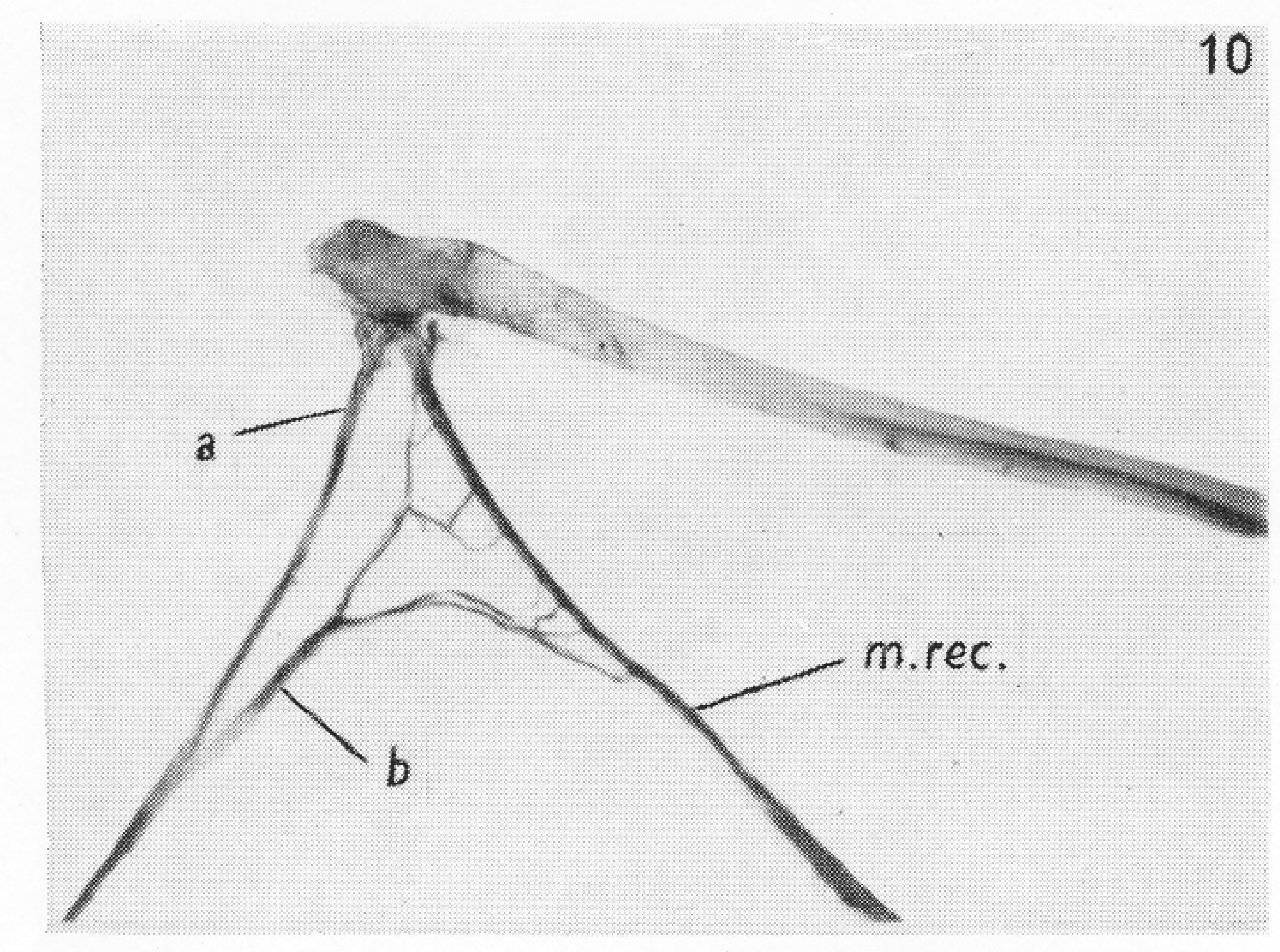

$2 \sqrt{\mathrm{m} m}$

12

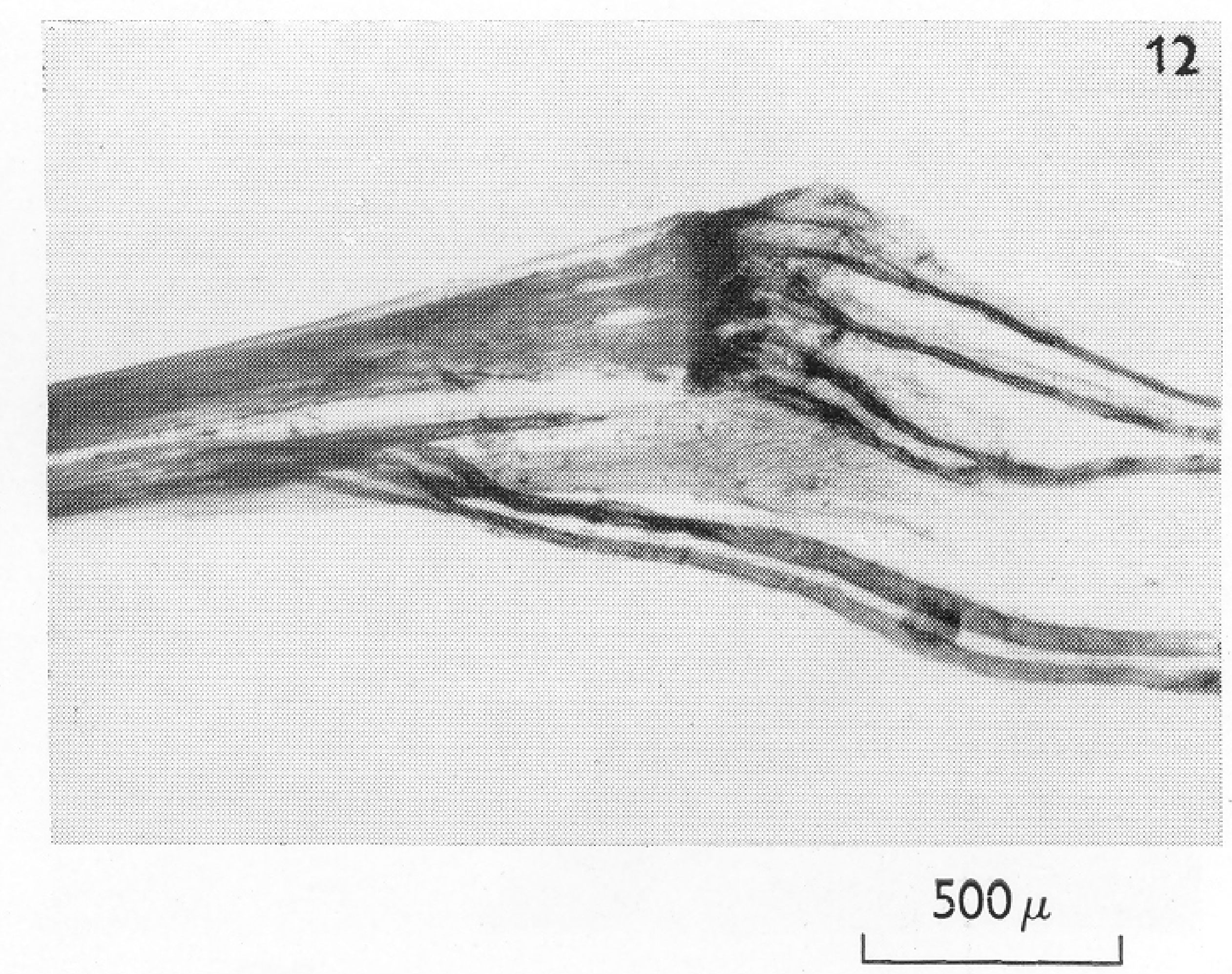

